NBER WORKING PAPER SERIES

\title{
CORRUPTING LEARNING: \\ EVIDENCE FROM MISSING FEDERAL EDUCATION FUNDS IN BRAZIL
}

\author{
Claudio Ferraz \\ Frederico Finan \\ Diana B. Moreira \\ Working Paper 18150 \\ http://www.nber.org/papers/w18150 \\ NATIONAL BUREAU OF ECONOMIC RESEARCH \\ 1050 Massachusetts Avenue \\ Cambridge, MA 02138 \\ June 2012
}

We are grateful to Brian Knight and two anonymous referees for several insightful comments that significantly improved the paper. We are also thankful to the staff at the CGU for support and clarifications of the auditing process, and to Elaine Pazzelo and Roberta Biondi for help with the education data. We thank David Card, Miguel Foguel, Seema Jayanchandran, Enrico Moretti, Ted Miguel, Sergei Soares, Fernando Veloso and seminar participants at BREAD, GRADE, Ibmec-Rio, IPEA-Rio, Notre Dame, PUC-Rio, RAND, USP for comments and suggestions. Tassia Cruz, Carolina Grottera, Susana Cordeiro Guerra, Marcio Nery, and Sinaia Urrusti-Frenk provided excellent research assistance. Financial support from CCPR and CNPq is gratefully acknowledged. The views expressed herein are those of the authors and do not necessarily reflect the views of the National Bureau of Economic Research.

NBER working papers are circulated for discussion and comment purposes. They have not been peerreviewed or been subject to the review by the NBER Board of Directors that accompanies official NBER publications.

(C) 2012 by Claudio Ferraz, Frederico Finan, and Diana B. Moreira. All rights reserved. Short sections of text, not to exceed two paragraphs, may be quoted without explicit permission provided that full credit, including $(\mathcal{C}$ notice, is given to the source. 
Corrupting Learning: Evidence from Missing Federal Education Funds in Brazil

Claudio Ferraz, Frederico Finan, and Diana B. Moreira

NBER Working Paper No. 18150

June 2012

JEL No. D73,H72,I21

\begin{abstract}
This paper examines if money matters in education by looking at whether missing resources due to corruption affect student outcomes. We use data from the auditing of Brazil's local governments to construct objective measures of corruption involving educational block grants transferred from the central government to municipalities. Using variation in the incidence of corruption across municipalities and controlling for student, school, and municipal characteristics, we find a significant negative association between corruption and the school performance of primary school students. Students residing in municipalities where corruption in education was detected score 0.35 standard deviations less on standardized tests, and have significantly higher dropout and failure rates. Using a rich dataset of school infrastructure and teacher and principal questionnaires, we also find that school inputs such as computer labs, teaching supplies, and teacher training are reduced in the presence of corruption. Overall, our findings suggest that in environments where basic schooling resources are lacking, money does matter for student achievement.
\end{abstract}

Claudio Ferraz

Department of Economics

PUC-Rio

Rio de Janeiro, RJ, 22453-900

Brazil

cferraz@econ.puc-rio.br

Frederico Finan

Department of Economics

University of California

508-1 Evans Hall \#3880

Berkeley, CA 94720-3880

and NBER

ffinan@econ.berkeley.edu
Diana B. Moreira

Department of Economics and

Harvard Business School

Harvard University

Cambridge, MA 02138

dmoreira@fas.harvard.edu 


\section{Introduction}

The focus of most education reforms around the world has been to provide more resources to public schools. But whether more resources lead to improvements in student outcomes is highly disputed, due in large part to the difficulties in evaluating these types of policies. ${ }^{1}$ The evaluation of policies aimed at providing more resources to schools is complicated for at least two reasons. First, those involved in the educational process may respond to the policy in ways that might dampen its effects - local officials may cut back on educational funding from local taxes or other revenue sources, teachers may feel less of a need to compensate for the lack of resources and in so doing provide less effort in the classroom or, similarly, parents might decide to provide less inputs at home. ${ }^{2}$ Second, resources transferred from higher level offices can be expropriated by the local government or school-level officials. In the presence of leakages, reported transfers to schools do not translate into school inputs. ${ }^{3}$

Evidence from cross-country data supports the idea that leakages can reduce educational quality. As seen in Figure 1, there is a strong negative association between a country's corruption level and its performance on international standardized exams. ${ }^{4}$ But there are several reasons why one should be cautious about interpreting this relationship as causal. First, there are many institutional and cultural differences across countries that determine both its level of corruption and the quality of education. Moreover, as it has been well documented, subjective cross-country measures of corruption are prone to important shortcomings (Svensson 2005). Thus, despite its importance, empirical evidence on the effects of leakages from educational funds on student outcomes remains remarkably sparse.

This paper examines the extent to which money matters in education by looking at whether missing resources due to corruption affect student outcomes. We use data from public schools in Brazil where locally-provided primary education is mostly funded by block grants from the central government. Brazil provides an ideal case to examine the effects of corruption in education. Despite significant expenditures on primary schooling per pupil,

\footnotetext{
${ }^{1}$ See for instance Hanushek (1996), Hedges, Laine, and Greenwald (1994), Glewwe and Kremer (2006).

${ }^{2}$ See Todd and Wolpin (2003), Das et al. (2011), Pop-Eleches and Urquiola (2011).

${ }^{3}$ Although the divergence of public sector resources is more common in developing countries (Reinikka and Svensson (2004)), there is also evidence that bureaucrats in developed countries also use creative accounting to divert funds (Baicker and Staiger (2005)).

${ }^{4}$ Figure 1 plots the relationship between the performance on the PISA international exams in 2006, after accounting for expenditures on primary schooling per pupil, and a country's corruption index. The PISA examination is available in 2006 for 56 countries when we include only those countries for which we also have information on spending in primary education per pupil. The corruption index is from Kaufmann, Kraay, and Mastruzzi (2009); we invert the sign of the corruption control index.
} 
students' performances on the PISA examination ranks among the worst in the world (see panels A and B of Figure 2). Even within Brazil, the association between spending per pupil and academic performance among primary school children in public schools is weak (see panels A and B of Figure 3). Finally, based on both official government audits and media reports, corruption involving education grants has become an overarching concern in Brazil.

To overcome the data constraints that have limited cross-country analysis, we build a novel dataset based on audit reports to quantify local-level corruption and mismanagement associated with grants earmarked for education. ${ }^{5}$ This data set, which represents one of the first large-scale attempts to measure corruption in education at a local level, has several advantages over the existing literature. ${ }^{6}$ First, we have corruption information about not only educational grants, but also transfers made in other sectors such as health and urban infrastructure. Because we can distinguish between corruption in education and corruption in other sectors, we can test whether our estimates reflect leakages from educational funds or simply capture the effects of overall corruption in the municipality. Second, the effects of corruption are identified separately from the effects of mismanagement practices in education. Corrupt politicians may have low management skills or hire poor managers, both of which may negatively affect educational outcomes. Our data allow us to distinguish between these different types of irregularities. ${ }^{7}$

We link municipal-level corruption measures to data on the educational achievement of primary school students across 1488 public schools located in 365 municipalities throughout Brazil. We use the variation in corrupt practices across municipalities to estimate the effects of "missing resources" on dropout rates, failure rates, and student achievement in a national standardized exam. We find that the educational outcomes of students residing in municipalities where corruption was uncovered are significantly lower than those of students residing in municipalities where no corruption was detected. For instance, test scores on a standardized Language and Math exam among $4^{\text {th }}$ graders are 0.30 standard deviations lower in corrupt municipalities. Corruption is also associated with higher dropout and failure rates among primary school children. We use complementary data sources to show that educational inputs are indeed lower in municipalities with more corruption. Based on Brazil's school census, we find that the percentage of teachers who had received pedagogical

\footnotetext{
${ }^{5}$ The data were constructed based on the audit reports used in Ferraz and Finan (2011), but exploiting the detailed reports from the educational grants.

${ }^{6}$ See Reinikka and Svensson (2004) for estimates of local capture of educational grants using expenditure tracking surveys.

${ }^{7}$ This is related to the distinction made by Bandiera, Prat, and Valletti (2009) on active and passive waste.
} 
training is 10.7 percentage points lower compared with non-corrupt municipalities. Schools in corrupt municipalities are also less likely to have a computer lab. From independent principals' and teachers' surveys, we also find that both teachers and principals of schools in municipalities where corruption was detected are much more likely to report the lack of resources and teaching supplies as being serious problems.

We undertake a series of robustness tests to make sure our results are indeed driven by "missing resources". First, we account for a large number of factors that are correlated with both corruption and test scores. These factors include not only the standard socioeconomic characteristics that have been showed to be associated with corruption (e.g. GDP per capita, urbanization, population size, and income inequality), but also many of the local institutional characteristics that allow the population to hold school managers accountable (e.g. presence of parent-teacher associations, elections for school principals, and the degree of community participation in school maintenance, etc). Second, we show that the results are robust to the control corruption measures detected in other sectors (e.g. health and infrastructure). Controlling for corruption in sectors other than education is likely to proxy for many of the unobservable characteristics that are both correlated with corruption in education and determine student achievement. It will also capture any indirect effects that corruption in other sectors might have on student achievement. ${ }^{8}$ Third, using the audit reports we also construct a measure of mismanagement of education resources. This allows us to disentangle the effects of corruption from the effects of mismanagement. Finally, we conduct a placebo test in which we examine whether corruption in education funds in the municipality affects the schooling outcomes of children attending private school. We do not find any evidence that public sector corruption is associated with the dropout and failure rates of children attending private school, suggesting that children are neither sorting into private schools nor that differences in education performance are driven by municipal-level unobserved characteristics.

Our findings contribute to the literature that examines whether resources matter for education. We show that a reduction in the availability of resources driven by corruption has negative effects on student outcomes. This is consistent with recent experimental and quasiexperimental evidence showing that increases in school inputs affect student outcomes (e.g.

\footnotetext{
${ }^{8}$ Given that we control for all these potential determinants of corruption, a subsequent question is what variation is used to identify the effects of corrupt practices on schooling outcomes. We present evidence showing that there is large variation in corrupt practices induced by how the Federal Government monitors and audits intergovernmental transfers in education. In particular, municipalities that have a larger share of educational funds from FUNDEF (Fundo de Manutenção e Desenvolvimento do Ensino Fundamental e de Valorização do Magistério), which is a program with weak monitoring, have more corruption.
} 
Muralidharan and Sundararaman (2011), Clark (2009), Duflo, Hanna, and Ryan (2010)). It is also consistent with Harbison and Hanushek (1992) who find that, when schools lack even the most basic resources such as infrastructure, textbooks, and teachers with completed secondary education, resources can have positive effects.

This study contributes, more broadly, to the literature on the consequences of corruption. While there is general consensus among academics and policy makers that corruption harms economic development, with few exceptions, the evidence is based on cross-country comparisons using subjective or self-reported measures of corruption (e.g. Mauro (1995)). Our study complements a growing literature showing that leakages from public funds create inefficiencies in the delivery of public goods and services. ${ }^{9}$

Our results are most closely related to Bjorkman (2007) and Reinikka and Svensson (2011); both use variation from an information campaign to measure the effects of a reduction in corruption on student outcomes. But our study differs in several respects. First, we provide evidence on the mechanisms linking corruption to student outcomes. We use a rich dataset of school infrastructure and teacher and principal questionnaires to show how school inputs, such as teachers with a higher education degree, computer labs, resources and teaching supplies, and teacher training are reduced in the presence of corruption. Second, we exploit the richness of the audit reports to build different measures of corruption and mismanagement.

The paper proceeds as follows. Section 2 provides an overview of Brazil's public education system and the corruption program that conducted the audit reports. In Section 3, we describe the data, including how our corruption measures were coded. Section 4 describes our conceptual framework and outlines our empirical strategy. Section 5 presents our results, and Section 6 concludes.

\section{Background}

\subsection{Decentralization and Block Grants for Education}

Brazil transfers over US $\$ 2.2$ billion in educational grants to municipal governments and spends 4.1 percent of its GDP on public education per year. Unfortunately, these expenditures have not led to significant improvements in academic performance. For instance, on

\footnotetext{
${ }^{9}$ See Chaudhury et al. (2006) who provide evidence on the widespread teacher and health worker absenteeism in developing countries; Olken (2006) who examines corruption in redistributive programs; Niehaus and Sukhtankar (2011) who examine leakages from public employment programs.
} 
the 2006 Programme for International Student Assessment (PISA) test among 15 year-old students, Brazil ranked 54th among 57 countries in mathematics and ranked 49th among 56 countries in reading. Brazil also placed well below Mexico and Argentina, both of which spend on average similar amounts on primary education.

Brazil's local governments bare much of the blame for this poor performance. The constitution dictates that state and municipal governments share the responsibility for the provision of primary and secondary education. In practice, however, most state governments manage secondary schools, while municipal governments manage primary schools (ensino fundamental). By 2005, approximately 85 percent of all first to fourth grade primary schools were managed by municipal governments. ${ }^{10}$ In order to guarantee adequate investments in education, Brazil's constitution mandates that at least 25 percent of all state and municipal revenues are spent for educational purposes. Local governments are thus responsible for building schools, providing adequate infrastructure, distributing school lunches and providing school transportation, training teachers, and paying salaries.

To cover these costs, the federal government transfers to states and municipalities large sums of resources in the form of block grants. ${ }^{11}$ Also, a new financing scheme named FUNDEF was created in 1997 to equalize the amount of resources available for education across regions. ${ }^{12}$ It consists of a state fund to which state and municipal governments contribute 15 percent of specific taxes and transfers. The fund, which totaled US $\$ 13.7$ billion in 2005 , is then redistributed to state and municipal governments on the basis of student enrollment. The federal government supplements local governments in states where per student allocations fall below an established spending floor. The FUNDEF constitutes a large share of resources available to mayors, but the use of resources is not completely unrestricted. For instance, the rule stipulates that at least 60 percent of FUNDEF revenues must be spent on teachers' salaries.

Despite being the largest block grant, FUNDEF is effectively left unmonitored. ${ }^{13}$ The principal reason for this lack of oversight has to do with the fact that no government agency

\footnotetext{
${ }^{10}$ See Madeira (2007) for details on the school decentralization process and its impact in the state of São Paulo.

${ }^{11}$ The largest block grant, called Fundo de Participação dos Municípios, was created in the 1960s and distributes resources to municipalities based on their population and the state's income per capita.

${ }^{12}$ See Gordon and Vegas (2005) and Menezes-Filho and Pazello (2007) for a detailed description of FUNDEF.

${ }^{13}$ In a report by Transparência Brasil, based on audits executed by the Controladoria Geral da União (CGU), the federal government controller's office, estimated that approximately $13 \%$ to $55 \%$ of FUNDEF's total budget between 2001 and 2003 was lost to fraud. Transparência Brasil (2005).
} 
was ever assigned to monitor the resources. ${ }^{14}$ According to the laws that govern FUNDEF, each municipality is required to transfer 15 percent of its revenue to a state fund that is then redistributed to municipalities based on the share of primary school students enrolled relative to total state enrollment. Since redistribution takes place within states, similar municipalities across different states receive different amounts of FUNDEF funds. If a minimum spending per pupil is not met then the federal government complements the amount municipalities receive. Because all three spheres of government (municipal, state and federal levels) contribute to this fund, the law does not specify which tier of government should be responsible for monitoring it. As a result, prior to the introduction of the audit program in 2003, the spending of these funds went largely unmonitored. ${ }^{15}$ Because of the lack of oversight associated with FUNDEF funds, we would expect corruption in education to be higher in places that receive a higher share of their educational resources from FUNDEF. We test this prediction in the next section.

\subsection{Embezzlement and Misuse of Educational Block Grants}

Cases of mayors diverting resources from these educational block grants are numerous. During 2005 alone, there were at least 26 news stories about the misuse of FUNDEF resources in the Brazilian press. ${ }^{16}$ Some examples are helpful to illustrate how ubiquitous the problem has become. In the municipality of Placas, in the North of Brazil, the ex-mayor could not account for US\$1.25 million of FUNDEF funds between 2003 and 2004. Moreover, when auditors asked the new mayor that took office in 2005 for documents and receipts, he said that all documents disappeared from the archives during the government transition. ${ }^{17}$ The new mayor of Camaragibe, state of Pernambuco, also had a surprise when he took office in January 2005. He discovered that US\$400,000 from the FUNDEF account was transferred by the ex-mayor to a private bank account. ${ }^{18}$

\footnotetext{
${ }^{14}$ Municipalities are required to establish local councils comprised of municipal government representatives, teachers, and parents to monitor the funds. Unfortunately, these councils have been mostly ineffective. They have either been captured by local mayors or do not meet regularly enough to effectively monitor the use of these resources (Transparência Brasil 2005). Yet, it is not too surprising that these local councils are unable to fulfill their role as an effective watchdog since local governments are under the control of elites and powerful mayors that often divert resources for their own benefits.

${ }^{15}$ In 2010, the Federal Auditors' Court (TCU) ruled that the legislation creating FUNDEF did not assign any entity to monitor the use of its resources and that it was not the responsibility of the National Fund for Educational Development (FNDE), the branch responsible for making all educational transfers of federal resources to municipalities.

${ }^{16}$ See www.deunojornal.org.br/busca.php?assunto $=463$

17 "Dinheiro do FUNDEF é o maior alvo de desvios", O Globo 06/25/2006.

18 "Desvio do FUNDEF atrasa salários de professores", O Globo 03/27/2005.
} 
It appears that embezzlement even extends to stealing teacher's wages, sparking frequent conflicts. In May 2009, approximately 90 percent of municipal school teachers in Itabuna, Bahia received less than half of their monthly salaries, after approximately US\$100,000 "disapeared" from the FUNDEF account. ${ }^{19}$ In the municipality of Senador Alexandre Costa, Maranhão, teachers did not receive their 13th monthly salary and bonus payment because the mayor had diverted all of the funds from FUNDEF. By April 2007, despite the school year having started in early February, all municipal schools were still closed and without electricity due to the lack of payments made. ${ }^{20}$ In Gonçalves Dias, Maranhão, 129 municipal teachers did not receive their salaries during 9 months in 2004. They went on strike and it was only in December that the municipal government paid part of their earnings. The new mayor, who inherited the debt, negotiated to pay only 40 percent of the back pay in exchange for having the new salaries paid on time. ${ }^{21}$

Mayors have engaged in other forms of coercion as well. For instance, in the municipality of Traipu, a geography teacher and local representative of the teachers' union, was transferred from an urban school where she taught geography to high school students to a rural school to teach small children after she denounced the mayor's misuse of educational grants. In the municipality of Viçosa, Alagoas students who participated in protests were forbidden to use the municipal bus that transports students to the only secondary school, which was located in the neighboring municipality. ${ }^{22}$ The small city of Satuba, Alagoas provides an extreme case of coercion. In June 2003, a teacher started a campaign to denounce the mayor for embezzling funds. Soon after, he was found tortured and killed.

While mayors have found ways of coercing teachers, this does not suggest that all cases of corruption go unpunished. In 2005 the Federal Police arrested 8 mayors and 4 ex-mayors in the state of Alagoas with charges of diverting US\$1 million from the FUNDEF. ${ }^{23}$ The ex-mayor of Cocal, in the state of Piauí, was also arrested for diverting US\$1.2 million from the FUNDEF. He had already been impeached from public office in 2008 under corruption allegations. $^{24}$ In December 2008, after a long investigation, the Federal Police arrested 9

\footnotetext{
${ }^{19}$ See "Professores de Itabuna recebem só metade do salario", in the Blog Pimenta na Muqueca, accessed in $05 / 04 / 2009$.

${ }^{20}$ Taken from a public complaint made by a citizen from Senador Alexandre Costa on a public email sent to Arlindo Chinaglia, the President of the National Congress, in April 2007.

${ }^{21}$ According to Francisco Carlos Custódio, the municipal Secretary of Education for Gonçalves Dias: "Many teachers were angry with the situation, but accepted the offer because they were afraid of not receiving their future salaries." (Desvio do FUNDEF atrasa salários de professores, O Globo 03/27/2005).

${ }^{22}$ See the report "Irregularidades na utilização de recursos públicos - Alagoas", written by the NGO Ação Educativa, available at http://www.acaoeducativa.org.br.

${ }^{23}$ See O Globo, "Dinheiro do FUNDEF é o maior alvo de desvios", 25/06/2006.

${ }^{24}$ See O Globo "PI: ex-prefeito é preso por desvios de fundo do Fundeb e do FUNDEF", Correio Braziliense,
} 
mayors, 7 municipal secretaries and 64 public servants for diverting resources from education and health funds in 16 municipalities in the state of Bahia. The police estimated that approximately US\$11.5 million was embezzled. ${ }^{25}$ In April 2009, the Federal Police arrested four ex-mayors and 17 other persons in the municipalities of Montes Altos, São Pedro da Água Branca, as well as Governor Edison Lobão, in the south of Maranhão. All of which were accused of diverting $\mathrm{R} \$ 6.5$ million from educational grants in $2008 .^{26}$

Given its prevalence in the education sector, corruption can severely impact a student's ability to learn in a variety of ways. First, when teacher salaries are delayed or not paid in full due to corruption, this can affect teacher motivation or the functioning of the school. Second, school quality is also compromised when funds intended for new classrooms or school supplies are diverted. Insufficient school inputs may not only have a direct effect on a student's ability to learn but can also affect a teacher's ability to teach. Third, corruption also occurs in the provision of school lunches. For children of poor households, these meals can represent an important source of daily calories. If corruption reduces the ability to retrieve these calories, then enrollment or regular attendance may suffer.

In sum, Brazil's local governments receive large sums of resources through educational block grants.A significant share of these resources is misused and diverted, thus affecting educational quality. Brazil's local governments provide an ideal setting to examine whether corruption at the local government level affects educational outcomes. Next, we describe Brazil's anti-corruption program and how we used its audit reports to build measures of misuse and diversion of resources from educational block grants.

\section{Data}

Our empirical analysis combines three different data sources. First, we use information contained in the audit reports of Brazil's anti-corruption program to construct our measures of corruption and mismanagement in the education sector. Second, we collect information on various schooling outcomes and student characteristics, which we aggregate at the school level. Third, we assemble a dataset containing information about the socio-economic characteristics of the municipality. Because the identifying variation is at the level of the municipality, accounting for differences across municipalities will be important for our analysis.

$01 / 30 / 2009$.

${ }^{25}$ See A Tarde, "Prefeitos envolvidos na Operação Vassoura-de-Bruxa devem ser ouvidos até sexta".

${ }^{26}$ See Estado de S.Paulo, "PF prende quatro ex-prefeitos e mais 17 pessoas no MA",04/28/2009. 


\subsection{Building Measures of Corruption and Mismanagement of Ed- ucational Funds}

Widespread corruption scandals in municipalities have led to a growing concern over the misuse of federal funds. In May 2003, the federal government started an unprecedented anticorruption program based on the random auditing of municipal government expenditures. The program, which is implemented through the Controladoria Geral da União (CGU), aims at discouraging the misuse of public funds among public administrators and fostering civil society participation in the oversight of public expenditures. The program began by auditing 26 randomly selected municipalities, one in each state of Brazil. It has since expanded to auditing 50 and later 60 municipalities per lottery, from a sample that includes all Brazilian municipalities with less than 450,000 inhabitants. The lotteries, which are held on a monthly basis at the Caixa Econômica Federal in Brasilia, are drawn in conjunction with the national lotteries. To ensure a fair and transparent process, the CGU invites representatives of the press, political parties, and civil society to witness the lottery. ${ }^{27}$

Once a municipality is chosen, the CGU gathers information on all federal funds transferred to the municipal government from 2001 onwards. Approximately 10 to 15 CGU auditors are then sent to the municipality to examine accounts and documents, to inspect for the existence and quality of public work construction, and delivery of public services. Auditors also meet with members of the local community, as well as municipal councils in order to collect direct complaints about any malfeasance. ${ }^{28}$ After approximately one week of inspections, the auditors submit a report containing, for each inspected area (e.g. education, health, urban infrastructure), a list of government programs audited, the total amount of federal funds transferred, and a detailed list describing each irregularity found. ${ }^{29}$ At the time of this study, audit reports were available for approximately 790 municipalities which were randomly selected through the first 16 lotteries of the anti-corruption program. From these 16 lotteries, we randomly selected the municipalities from 10 lotteries to measure corruption and mismanagement in education, health, and urban infrastructure, which are the three largest sources of federal transfers for municipalities. ${ }^{30}$ Thus, in total, we construct indicators of corruption and mismanagement for 366 municipalities.

\footnotetext{
${ }^{27}$ See Ferraz and Finan (2008) for a more detailed description of these audits.

${ }^{28}$ These auditors are hired based on a public examination, and prior to visiting the municipality receive extensive training on the specificities of the sampled municipality. Also, there is a supervisor for each team of auditors.

${ }^{29}$ For some irregularities, the amount of resources diverted are estimated by the auditors.

${ }^{30}$ As a result, we do not have data from lotteries $8,11-13$, and 15 .
} 
In order to build our measures of corruption and mismanagement, we read the report for each municipality and classify the irregularities listed by the auditors into several preestablished categories. We define three types of corruption practices: diversion of public funds, over-invoicing, and irregular public procurements. We classify diversion of resources as any irregularity involving the embezzlement of public funds. This typically occurs in one of two situations: 1) federally-transferred resources simply "disappear" from municipal bank accounts; and 2) the municipality claimed to have purchased goods and services that were never provided, which is determined when there is no proof of purchase and community members confirm that the goods were in fact not delivered. We classify over-invoicing as any irregularity in which auditors determined that the goods and services were purchased at a value above market price. We classify the irregularity as an irregular public procurement when there is an illegal call-for-bids and the contract is awarded to a "friendly firm". These firms are usually connected directly to the mayor and/or his family or some cases do not exist. Most cases of corruption involving illegal public procurements include any combination of: i) use of non-existing firms in the bidding process; ii) use of fake receipts to pay for goods and services; iii) over-invoicing of prices to increase the amount paid for the goods and services.

Drawing on the classifications described above, we define three measures of corruption. First, an indicator for whether auditors detected any corruption in education. Second, we count the number of irregularities associated with corruption and divide by the number of service items audited. Third, we estimate the value of resources diverted (when information is available) and divide it by the amount of resources in education that were audited. ${ }^{31}$ While the second and third measures capture the extent of corruption, corruption in education was only detected in 35 percent of municipalities, suggesting that the extensive margin may capture most of the relevant variation in the data. So while we present results using all three measures of corruption, most of our analysis will focus on the corruption indicator.

In addition to documenting the cases of corruption, we also construct measures of mismanagement. These are irregularities that are uncovered by the auditors, but do not involve any incidence of fraud. Administrative irregularities, however, may still affect the quality of education if they create inefficiencies in the allocation of school inputs. Some examples are useful to illustrate this measure. Municipalities that receive funds from the FUNDEF program are required to establish an active and independent community council to monitor the use of these funds. Auditors uncovered several cases where the council simply did

\footnotetext{
${ }^{31}$ Because some of the irregularities associated with corruption have missing values, the share of corruption is underestimated.
} 
not function. It either never met or was led by a mayor's family member. Although this irregularity is not an act of corruption, the lack of a well functioning council prevents the effective use and monitoring of resources by civil society. Another common form of mismanagement is the use of resources that are mandated for other purposes. For instance, mayors have to spend at least 60 percent of resources from FUNDEF on teacher salaries. In some municipalities, auditors discovered that these resources were used to pay for the salaries of other public servants or to purchase gasoline for municipal cars. Again, even though this does not constitute the diversion of resources for private gains, it may affect the allocation of resources intended for education. Finally, public procurements require at least three firms to participate in the call-for-bids. Even in the case where the public good or service was provided (and is thus not considered corruption) the lack of competition in the bidding process might have led the government to overspend, thus creating distortions in the allocation of resources. For mismanagement, most irregularities are not associated with values (e.g. lack of a council to monitor the use of funds) and virtually every municipality has some incident of mismanagement. Thus, we can only build measures of mismanagement by counting the total number of irregularities.

Table 1 presents summary statistics of the corruption measures. Corruption in the area of education was discovered in 35 percent of municipalities. Among these municipalities, 35 percent of service items in education were found to be subject to corruption and 8 percent of resources were diverted. Corruption in other sectors was also discovered in 50 percent of the municipalities, and on average 2 irregularities per service item were found to be associated with some type of mismanagement.

\subsection{Data on Schooling Outcomes and Municipal Characteristics}

We have two main sources of schooling data, both of which are aggregated at the school level. The data on test scores and student characteristics come from a national standardized examination of 4th and 8th graders called Prova Brasil. In 2005, the Federal government conducted a standardized exam in the subjects of Mathematics and Portuguese given to all 4th graders enrolled in a public school with at least 20 students. In addition to the exam, the program conducted a survey designed to measure the child's socio-economic conditions. The survey includes not only information about the child, such as gender, age, and race, but also information about their parents and home environment: such as the education of the parents, whether the child lives with both parents, size of the family, whether the household owns a computer and other assets. The wealth of information contained in the survey allows 
us to control for a host of characteristics that are likely to affect student achievement.

Our second principal data source comes from the 2005 and 2006 school census, referring to information from the 2004 and 2005 school year respectively. The census measures the basic conditions of schools in Brazil. It contains information about approval rates, dropout rates, and failure rates by school. There is also information regarding school conditions such as whether the school has sanitation, or computer and science labs, as well as information about teachers, namely years of experience and what proportion have a degree or a credential.

Table 2 provides summary statistics based on information from these surveys, as well as basic socio-economic information about the municipality. We see that the proportion of children with parents with at least high school degree is on average 16 percent. On average 15 percent of children have a computer at home. The average dropout rate for schools in our sample is 4 percent, while failure rates are at 10 percent. Only 19 percent of schools have a computer lab and 4 percent of schools have a science lab.

From the 2007 Prova Brasil, we also have responses from a principal's survey and a teacher's survey. These surveys, which were conducted separately, asked whether the following four items were a serious concern at school: 1) lack of financial resources 2) lack of school supplies 3) lack of teachers to teach the courses 4) disciplinary problems among the student body. In both the teacher's and principal's surveys, 55 percent of the schools cite lack of resources and school supplies as serious concerns. Only 23 percent cite lack of teachers as an important concern.

Combining the test score data with the information from the audit reports, Figure 4 plots the distribution of test scores by whether or not corruption in education was detected in the municipality. Consistent with the cross-country evidence, we find that the distributions of scores for both math and language in corrupt municipalities is to the left of the distributions of scores in municipalities where corruption was not found. On average, test scores are 15 points lower in municipalities where some corruption in education was detected. We later investigate the robustness of this relationship.

\section{Empirical Strategy}

To estimate the effects of corruption on student achievement, let us assume that the academic achievement $A_{i, s, m, t}$ of an individual $i$ attending school $s$ in municipality $m$ in grade $g$ is 
determined by the following reduced-form equation:

$$
A_{i, s, m, g}=\delta A_{i, s, m, g-1}+\gamma_{g}\left(Y_{m, g}-C_{m, g}\right)
$$

where $Y_{m, g}$ is the amount of the education funds per school, and $C_{m, t}$ is the amount per school that is diverted. ${ }^{32}$ The parameter $\gamma_{g}$ measures the effect of schooling resources on student performance, which may vary by grade level, and $\delta$ captures how much learning decays from one grade to the next. Under this value-added specification, a student's achievement at the end of the fourth grade is given by the following expression:

$$
A_{i, s, m, 4}=\sum_{g=1}^{4} \delta^{4-g} \gamma_{g}\left(Y_{m, g}-C_{m, g}\right)+\delta^{4} A_{i, s, m, 0}
$$

Given that our measure of corruption captures the average amount of diversion in education over a three-year period, and we assume that corruption does not vary much across grades, we can rewrite the equation above as:

$$
A_{i, s, m, 4}=\beta C_{m}+\delta^{4} A_{i, s, m, 0}+\sum_{g=1}^{4} \delta^{4-g} \gamma_{g} Y_{m, g}
$$

where $\beta=-\sum_{g=1}^{4} \delta^{4-g} \gamma_{g}$. After averaging across students within a school, we arrive at the our estimation equation:

$$
A_{s, m, 4}=\alpha+\beta C_{m}+Z_{m}^{\prime} \theta_{1}+X_{s, m}^{\prime} \theta_{2}+\epsilon_{s, m}
$$

where $A_{s, m, 4}$ is the average student achievement of fourth graders in school $s$ in municipality $m, C_{m}$ is the level of corruption in education that was detected in the municipality, and $X_{s, m}$ is a vector of predetermined student characteristics (e.g. gender, age, race, etc.) and family characteristics (e.g. parent's education, assets, etc.) that will account for differences in the initial student achievement, $A_{s, m, 0}$, of the student body. To proxy for $\sum_{g=1}^{4} \delta^{4-g} \gamma_{g} Y_{m, g}$, we control for total expenditure in primary school which is included in the vector $Z_{m}$ along with a set of other municipal characteristics. The variable $\epsilon_{s, m}$ denotes a random error term that is clustered at the school level. Given the value-added specification and under the assumption

\footnotetext{
${ }^{32}$ We are assuming that the municipality's education budget is distributed evenly across schools, which is why we drop the schooling subscript, $s$. Thus, we do not consider the possibility that corruption affects one school disproportionately more than another.
} 
that $E\left[C_{m} \epsilon_{s, m} \mid X_{m} Z_{s, m}\right]=0$, the coefficient $\beta$ captures the discounted cumulative effects of corruption on student performance since the first grade.

Given our identification assumption, there are three broad classes of factors that are likely to affect our ability to interpret the causal effects of corruption on student achievement. First, as we know from the cross-country literature, corruption is not only negatively correlated with economic development, but test scores are also on average lower among countries that are less economically developed. In wealthier places, households will invest more in their children's education both because they have more financial resources to do so, and because the returns to education might be higher due to different types of economic activities. In our regressions, we account for a municipality's level of economic development using municipal GDP per capita. We also control for other socio-economic characteristics that have been shown to be associated with corruption, such as urbanization, population size, and income inequality. ${ }^{33}$ Second, local institutions that hold school managers accountable to the population are likely to improve school performance and reduce corrupt practices in education. We use detailed institutional data to control for the presence of parent-teacher associations, elections of school principals, and the degree of community participation in school maintenance. Third, the education policies of a municipality also reflect the preferences of the mayor. Mayors who care more about education will presumably be less willing to divert money away from education. To account for the mayor's preferences towards education, we control for several characteristics of the municipality and the mayor: the amount of ostensible spending per pupil, whether the municipality has an intergovernmental consortium in education, whether a school council exists, as well as the mayor's gender and schooling level.

In Table 3, we examine how these various characteristics correlate with our measures of corruption in education. Each column uses a different measure of corruption and for each one we estimate both a basic OLS model and a non-linear model accounting for corner solutions. Overall, the results suggest that municipalities with a larger urban population and greater inequality are associated with more corrupt practices, while municipalities that hold elections for school principals, that have a school council, and where the mayor holds a college degree are associated with less corruption. ${ }^{34}$

Given that our most robust specification controls for all these potential determinants of corruption, a natural question becomes: what is the variation that allows us to identify the effects of corrupt practices on schooling outcomes? The identifying variation comes

\footnotetext{
${ }^{33}$ See for instance Ades and Di Tella (1999), Glaeser and Saks (2006), Glaeser, Scheinkman, and Shleifer (2003), La Porta et al. (1999), Reinikka and Svensson (2004), and Treisman (2000).

${ }^{34}$ The results for the share of audited resources with corruption in education are less precisely estimated.
} 
from how the Federal Government monitored and audited intergovernmental transfers in education prior to the introduction of the CGU audit program. As we discussed in Section 2, municipalities fund their expenditures in education through a variety of sources. These funding sources, however, are subjected to different degrees of monitoring under Federal law. Consequently, municipalities receiving the same amount of educational resources can experience, for arguably exogenous reasons, quite different degrees of monitoring.

To see how variation in the degree of monitoring might affect corruption, consider the case of FUNDEF. As we mentioned previously, despite the fact that FUNDEF represents almost 80 percent of the intergovernmental transfers used for education, these funds are essentially unmonitored. Thus, we would expect more corruption in education in places that receive a higher share of their educational funding from FUNDEF. In the first row of Table 3 we find that municipalities with a larger share of revenues from FUNDEF have, on average, more corrupt practices: a one standard deviation increase in the share of educational funds from FUNDEF increases the probability of corruption in education by 8 percentage points, or 23 percent. This result is consistent with the idea that the decentralization of responsibilities financed by intergovernmental transfers, rather than local revenue collection, allow local officials to ignore the consequences of mismanagement because they are less accountable to local taxpayers. ${ }^{35}$

Even after controlling for the observable characteristics described above, we might still be worried that municipalities with less corruption may offer more public goods and other amenities that might affect student achievement. For instance, mayors who care about education may also care about improvements in health, and may also refrain from corruption in the health sector. Because the health of a child is also likely to affect his academic achievement, our estimates may also be capturing the effects of less corruption in the health sector. It may also be the case that families that value education may choose to live in municipalities with less corruption. In these situations, we will over-estimate the negative effects of corruption on education. ${ }^{36}$

To address these concerns, we present several robustness checks. First, we re-estimate Equation (1) controlling for corruption detected in other sectors (e.g. health and infrastructure). Controlling for corruption in sectors other than education is likely to proxy for many of the unobservable characteristics that are both correlated with corruption in education and determine student achievement. It will also capture any indirect effects that corruption in

\footnotetext{
${ }^{35}$ See Fan, Lin, and Treisman (2009); Fisman and Gatti (2002)

${ }^{36}$ If parents in corrupt municipalities compensate for the lack of schooling inputs then we would underestimate the negative effects of corruption.
} 
other sectors might have on student achievement. Second, using the audit reports we also construct a measure of mismanagement of education resources. This allows us to disentangle the effects of corruption from the effects of mismanagement.

Our third main robustness check uses private schools as a placebo test. Here, we reestimate Equation (1) using educational outcomes of children who attend private school as the dependent variable. Under this specification, we would expect $\hat{\beta}=0$, since corruption in public expenditures should not affect private school outcomes. Similarly, we also test whether the effects of corruption on educational outcomes differ in municipalities with private schools by estimating the following equation:

$$
A_{s m}=\alpha+\beta C_{m}+\eta_{1} P_{m}+\theta\left(P_{m} \times C_{m}\right)+Z_{m}^{\prime} \delta+X_{s, m}^{\prime} \gamma+\epsilon_{s m}
$$

where $P_{m}$ is an indicator for whether a private school exists in the municipality. If in corrupt municipalities more able students are sorting into private schools, then we would expect the interaction effect between corruption and the existence of a private school to be negative, i.e. $\theta<0$.

\section{$5 \quad$ Results}

In this section we present the main empirical results of the paper. We begin by presenting estimates of the relationship between schooling outcomes and corruption in education. We then show that our estimates are robust across various specifications, including ones that control for the effects of mismanagement and corruption in other sectors. In the final part of the section, we explore the mechanisms that link corruption to poor schooling achievement.

\subsection{The effects of corruption practices on educational outcomes}

Table 4 reports estimates of the association between corruption and various schooling outcomes measured in 2005. The results are OLS estimates of a series of regression models based on Equation (1). Our base specification, which is reported in the odd columns, adjusts for several key school characteristics (e.g. gender, race, age, parent's education, household wealth, student-teacher ratio) which are likely to affect the education production function. In the even columns, we augment this base specification to also include various characteristics 
of the municipality (e.g. GDP per capita, population, Gini). ${ }^{37}$

Panel A presents estimates using as our measure of corruption the proportion of audited education items found to involve corruption. Across the various schooling measures, the negative effects of corruption are substantive. For instance, a 30 percentage point (or approximately one standard deviation) increase in corruption is associated with a 0.10 standard deviation decrease in test scores (columns 2 and 4), and a 0.6 percentage point increase in both dropout and failure rates (columns 6 and 8). These point estimates, while economically meaningful, are also highly robust to the inclusion of important controls that account for differences in labor market opportunities, such as GDP per capita and urbanization rates.

In Panel $\mathrm{B}$, we present estimates using the share of resources in education found to be corrupt as an alternative measure of corruption. In reading the audit reports, it is difficult to calculate a dollar amount for every irregularity. Yet despite the imprecision associated with this measure, the results in Panel B convey a similar story. In columns 2 and 4 of Panel $\mathrm{B}$, the estimates imply that a 5 percentage point increase in corruption is associated with a 0.04 standard deviation decrease in test scores. The share of audited resources found to be corrupt is also positively associated with both dropout and failure rates, but imprecisely estimated.

In Panel C, we present a third alternative corruption measure: an indicator for whether or not corruption in education was detected. The result suggests that children residing in municipalities where corruption was detected fare much worse on the standardized exams than those with similar observable characteristics but residing in municipalities where no corruption was revealed. Based on the estimates presented in column 1, corruption in education is associated with a significant decrease of 0.35 standard deviations in test scores (robust standard error $=0.076$ ).

While columns 1-4 suggest that corruption may have affected learning, the results in columns 5-8 indicate that corruption may also affect a child's educational attainment. Dropout rates are 2.9 percentage points higher in municipalities where corruption was detected, representing almost a 65 percent increase from the average. Failure rates are also higher in corrupt municipalities (see column 7 and 8), thus consistent with the effects on test scores.

While all three alternative measures of corruption produce similar results, the measures

\footnotetext{
${ }^{37}$ While a more robust specification would also include state-fixed effects, 9 out of the 25 states have 1 or fewer municipalities with corruption in education, which constitutes close to 40 percent of observations in our sample. Thus when we incorporate state fixed-effects, we are either losing the contribution of certain states that do not have any variation or introducing a lot of measurement error given that our averages for the "treatment group" are based on a single observation. Nevertheless, when relying on within state variation, the point estimates, while less precise, are still negative.
} 
presented in panels A and B have the potential advantage of capturing the effects of corruption along the intensive margin. However, given that only 35 percent of municipalities have some practice of corruption in education, the relevant variation in the data may simply be reflected in the extensive margin. In Figure 5, we plot the relationship between test scores and the proportion of items audited associated with corruption. As we see from this figure, the effects of corruption, while decreasing, are statistically similar once the proportion of items is larger than 0.1. While this relationship might appear puzzling, it is likely to reflect the fact that this measure does not capture the amount of resources diverted. Thus, committing one big act of corruption versus many small acts of corruption may affect education similarly. This explanation is consistent with what we see in Panel B when we plot the relationship between test scores and the share of resources involving corruption. Here, we find a much more consistently negative relationship between corruption and test scores, although as we mentioned previously, this variable is measured with much more noise. ${ }^{38}$ For these reasons, in the remainder of the analysis, we use the indicator for whether or not corruption in education was detected as our main measure of corruption.

Overall, the results presented in Table 4 suggest that the effects of corruption on education outcomes are quite severe. Our findings are however comparable to those presented by Reinikka and Svensson (2011), who find that a 30 percentage point increase (or approximately one standard deviation) in corruption is associated with a 0.10 standard deviation decrease in test scores. Because their measure of leakage is continuous, we can compare this effect with our point estimates in Panel B of Table 4. When based on the share of resources associated with corruption, our estimates imply that an increase in corruption of 20 percentage points (or approximately one standard deviation) is associated with a reduction in test scores of 0.14 (for Math) and 0.18 (for Portuguese) standard deviations. Although our estimates appear slightly larger, recall that our measure of leakage represents an average over a 3 year period. Thus, our effects are in fact slightly smaller than those reported by Reinikka and Svensson (2011) whose measure of leakage is based on a single year.

\footnotetext{
${ }^{38}$ Given these figures, it is perhaps not surprising that the correlation between the proportion of items found to be corrupt and the share of resources found to be corrupt is only 0.29 .
} 


\subsection{Robustness Checks}

\section{Controlling for Institutional Quality, School Institutions, and Educational Pref- erences}

In Table 5 we re-estimate our main specification controlling for corruption in other sectors, as well as other measures of institutional quality at the local level (e.g. whether members of the community participates in the budgetary process or has a judiciary district). This specification is useful for two reasons. First, it identifies the effects of corruption specifically in education, rather than potentially estimating a proxy for more general corruption. Second, by controlling for corruption in other sectors and other measures of institutional quality, we are accounting for many of the unobserved differences between municipalities that do and do not engage in corruption more generally. For instance, returns to education are often lower in places that are more prone to corruption, since these areas tend to be economically depressed and more reliant on local patronage practices. With this specification, we are, for example, able to capture any potential differences in the returns to education that were not necessarily accounted for by controlling for income levels.

Corruption in other sectors also has a strong negative correlation with educational outcomes. For instance, in column 1 of Table 5, corruption in other sectors is associated with a 0.2 standard deviation decline in test scores, which is comparable to our main effects. This estimate reflects the fact that corruption in other sectors may not only be serving as an important proxy for other institutional characteristics of the municipality that adversely affect test scores, but is also capturing the negative indirect effects that corruption in sectors, such as health and sanitation, can have on test scores. We also see that even after controlling for whether corruption in other sectors was detected, our estimates remain virtually unchanged. Overall, these results suggest that our estimates are robust to unobservable factors that affect both schooling outcomes and a municipality's propensity to engage in corruption more broadly. ${ }^{39}$

In the even columns of Table 5, we re-estimate the main regression model controlling for a series of variables intended to capture differences in either preferences or local institutions specific to education. These variables either directly capture the efficacy of local schools and parent organizations (active PTA, existence of a school council) or serve as proxies for the general level of civic engagement in the municipality (e.g. principal is elected, municipality

\footnotetext{
${ }^{39}$ Even after controlling for corruption in other sectors, we cannot of course rule out the possibility that other forms of unobserved heterogeneity are biasing our results.
} 
uses participatory budgeting) ${ }^{40}$ Our original results are again robust to controlling for these additional local institutions.

\section{Does the misuse of public funds affect educational performance in private schools?}

In Table 6, we present alternative tests for whether unobserved differences between corrupt and non-corrupt municipalities are affecting our results. In Columns 1 and 2, we estimate the effects of corruption in education on the dropout and failure rates of children attending private schools. ${ }^{41}$ Because our measure of corruption is based on the misuse of funds intended for public schools, we should not expect the measure to predict educational outcomes of private-school children. The results in columns 1 and 2 do in fact show that the effects of corruption on private schooling outcomes are small and statistically insignificant.

Although we do not find that corruption affects the dropout and failure rates of private school children, an alternative explanation for our results is that corruption influenced the selection of students into public and private schools. We test this hypothesis in columns 3-7. In column 3, we estimate whether children are more likely to enroll in private schools in municipalities with corruption. In columns 4-7, we estimate whether the effects of corruption on educational outcomes are more pronounced in municipalities where a private school exists. If in municipalities with corruption high ability students are more likely to attend private schools, then we should expect the effects of corruption to be more pronounced among municipalities with a private school. But as we see in columns 3-7, corruption does not predict enrollment rates among private schools and its effects are not more pronounced in municipalities with a private school. This suggests that differential sorting does not explain our findings.

\section{Corruption or mismanagement?}

Another possible concern is that our estimates capture the effects of not only the diversion, but also the mismanagement of educational resources. If corruption and mismanagement of educational funds are positively correlated, then our estimates are overstated. Table

\footnotetext{
${ }^{40}$ Intergovernmental consortiums are entities managed by civil society. They group municipalities to implement a certain action that individual municipalities are not capable of doing alone. They have autonomous management and financing and are commonly used to provide public services, e.g. management of a public hospital. Participatory budgeting is a type of participatory democracy, in which citizens are formally given the opportunity to discuss and prioritize public spending projects, and in some cases even decide how to allocate parts of the municipal budget.

${ }^{41}$ Unfortunately, standardized Mathematics and Portuguese exams are only conducted on students attending public schools.
} 
7 shows that this is not the case. In columns 1-4, we re-estimate the full specifications presented in Table 3, controlling for the share of audited items in education associated with mismanagement practices. Our findings in columns 1 and 2 suggest that test scores are in fact negatively correlated with the incidence of mismanagement. A one standard deviation increase in the incidence of mismanagement is associated with a 0.14 standard deviation decrease in math scores. Yet despite this negative correlation, the magnitude of the effect is small relative to the size of the effects of corruption. The incidence of mismanagement in a municipality would have to increase from the 1st percentile to the 99th percentile of the distribution in order to achieve the same effects as those of corruption. Overall, the estimated coefficients across the various educational outcomes suggest substantive effects of corruption, even after accounting for the negative effects of mismanagement.

\subsection{Mechanisms linking corruption to educational outcomes}

Thus far, we have presented estimates of a reduced-form relationship between corruption in education and student achievement. As discussed in Section 4, corruption can affect student performance through various channels. The direct channel we examine here is the reduction of school inputs and/or infrastructure. In Table 8, we explore whether schooling inputs are lower in municipalities where corruption was detected using data from the 2005 school census.

Column 1 examines whether corrupt municipalities are less likely to have received pedagogical training. One common form of corruption uncovered in the audits was the diversion of funds intended for teacher training. The results in column 1 confirm this hypothesis. In municipalities where corruption was detected, the percentage of teachers who are trained is 11.3 percentage points (standard error 0.061) lower compared to non-corrupt municipalities. Given that 44 percent of teachers receive training, this estimate represents a 25 percent decline. Schools in corrupt municipalities are also less likely to have a computer lab (coefficient $=-0.060$; standard error $=0.026$ ), but we find no effects on the likelihood of having a science lab (coefficient=-0.008; standard error $=0.013$ ). We do not find any evidence that schools in corrupt municipalities have less access to sanitation, but this might be a margin where corruption is harder to hide. Also, from the results presented in the even columns, our estimates are robust to controlling for school inputs in 2001.

Table 9 provides further evidence that schools have fewer resources in municipalities where corruption in education was detected. Table 9 presents estimates based on a series of linear probability models, where the dependent variable is specified at the top of each 
column. Each dependent variable is constructed based on a series of questions asking teachers and principals whether the school faced the following non-mutually exclusive problems: 1) insufficient resources; 2) insufficient teaching supplies; 3) lack of teachers; 4) disciplinary problems among the students. In columns 1-4, we present estimates based on information from a teacher's survey, whereas the estimates presented in columns 5-8 are based on responses to the same question, but asked separately to the school principal.

Despite the fact that the two surveys were conducted separately, both teachers and principals of schools in municipalities where corruption was detected are much more likely to report a lack of resources as a serious problem. For instance, in corrupt municipalities, teachers are 7.2 percentage points (standard error $=0.034$ ) more likely to indicate a lack of teaching supplies (see column 2), whereas school directors are 10.6 percentage points (standard error $=0.035$ ) more likely to complain about a lack of teaching supplies (see column 6 ). While corruption would be expected to lead to fewer resources, one would not necessarily expect corruption to affect disciplinary problems among students or even a lack of teachers (at least in the short run). The data do in fact bear this out. In columns 3-4 and 7-8, we do not find any association between corruption in education and whether the school faces

disciplinary problems among its students or a lack of teachers. Using information from the principal's survey, we investigate whether schools in corrupt municipalities are less likely to offer pedagogical training. As reported in column 9, we find that teachers of schools in corrupt municipalities are 10.6 percentage points less likely to have gone through teacher training. This result is consistent with the finding presented in Table 8.

\section{Conclusions}

Improving school quality remains a challenge faced by most developing countries. But how to improve quality is still a highly debated question. In this paper, we present evidence that leakages from educational resources can be an important constraint on school quality. Using a novel dataset of corruption in education and schooling outcomes across public schools in Brazil, we find that student test scores on a national standardized exam and pass rates are significantly lower, and dropout rates are significantly higher in municipalities where corruption is prevalent.

Consistent with the idea that corruption reduces schooling inputs, we find that schools in municipalities found to be corrupt have less school infrastructure and teachers that have received training. Moreover, both teachers and principals report the lack of resources as a 
principal concern in corrupt municipalities. Thus, our results contradict a large literature suggesting that additional resources do not affect schooling outcomes. We conclude that, in environments where basic schooling resources are lacking, money does matter for educational achievement. To the extent that the quality of education affects long-run economic growth, our results suggest a direct channel through which corruption affects long-run economic development (Hanushek and Woessmann 2009).

Our findings have important policy implications. First, they suggest that efforts to increase school quality in developing countries need to incorporate policies that aim at reducing leakages. Introducing a system to monitor the use of educational funds, including block grants, should be of central concern to governments. Moreover, it can be a costeffective way to improve schooling outcomes. Second, in addition to corruption, we find that the mismanagement of resources have detrimental effects on students' performance. These findings complement the work of Bandiera, Prat, and Valletti (2009) who show that passive waste in public service might be as important as active waste in generating public-sector inefficiencies. Thus, reforms aimed at improving the capabilities of local bureaucracies may help reduce inefficiencies in the use of public funds.

Although our results focus on the direct effects of corruption-induced leakages, the negative effects of corruption on schooling may not simply represent a shift in the school budget constraint. If, for instance, corruption also affects the allocation of school inputs - perhaps to avoid detection - then corruption can lead to important distortionary effects as well (Shleifer and Vishny 1993). Future research should address these additional costs of corruption. 


\section{References}

Ades, Alberto, and Rafael Di Tella. 1999. "Rents, Competition, and Corruption." American Economic Review 89 (4): 982-993 (September).

Baicker, Katherine, and Douglas Staiger. 2005. "Fiscal Shenanigans, Targeted Federal Health Care Funds, and Patient Mortality." Quarterly Journal of Economics 120 (1): 345-386.

Bandiera, Oriana, Andrea Prat, and Tommaso Valletti. 2009. "Active and Passive Waste in Government Spending: Evidence from a Policy Experiment." American Economic Review 99 (4): 1278-1308.

Bjorkman, Martina. 2007. "Does Money Matter for Student Performance? Evidence from a Grant Program in Uganda." IGIER Working Paper n. 326, August.

Chaudhury, Nazmul, Jeffrey Hammer, Michael Kremer, Karthik Muralidharan, and F. Halsey Rogers. 2006. "Missing in Action: Teacher and Health Worker Absence in Developing Countries." Journal of Economic Perspectives 20 (1): 91-116 (Winter).

Clark, Damon. 2009. "The Performance and Competitive Effects of School Autonomy." Journal of Political Economy 117 (4): 745-783.

Das, Jishnu, Stefan Dercon, James Habyarimana, Pramila Krishnan, Karthik Muralidharan, and Venkatesh Sundararaman. 2011. "School Inputs, Household Substitution, and Test Scores." Mimeo, UCSD.

Duflo, Esther, Rema Hanna, and Stephen P. Ryan. 2010. "Incentives Work: Getting Teachers to Come to School." American Economic Review, vol. Forthcoming.

Fan, C. Simon, Chen Lin, and Daniel Treisman. 2009. "Political decentralization and corruption: Evidence from around the world." Journal of Public Economics 93 (1-2): 14-34 (February).

Ferraz, Claudio, and Frederico Finan. 2008. "Exposing Corrupt Policiticans: The Effects of Brazil's Publicily Released Audits on Electoral Outcomes." Quarterly Journal of Economics 123 (2): 703745.

- 2011. "Electoral Accountability and Corruption: Evidence from the Audits of Local Governments." American Economic Review 101 (June): 1274-1311.

Fisman, Raymond, and Roberta Gatti. 2002. "Decentralization and corruption: evidence across countries." Journal of Public Economics, no. 83:325345. 
Glaeser, Edward, Jose Scheinkman, and Andrei Shleifer. 2003. "The injustice of inequality." Journal of Monetary Economics 50 (1): 199-222 (January).

Glaeser, Edward L., and Raven E. Saks. 2006. "Corruption in America." Journal of Public Economics 90:1053-1072.

Glewwe, Paul, and Michael Kremer. 2006. "Schools, Teachers, and Education Outcomes in developing Countries." In Handbook on the Economics of Education, edited by Erik Hanushek and Finis Welchh. Oxford: Elsievier.

Gordon, Nora, and Emiliana Vegas. 2005. "Educational Finance, Equalization, Spending, Teacher Quality, and Student Outcomes: the Case of Brazil's FUNDEF." In Incentives to Improve Teaching: Lessons from Latin America, edited by Emiliana Vegas. Washington D.C.: The World Bank.

Hanushek, Eric A. 1996. "School Resources and Student Performance." In Does Money Matter? The Effect of School Resource on Student Achievement and Adult Success, edited by Gary Burtless. Washington, D.C.: Brookings Institution.

Hanushek, Eric A., and Ludger Woessmann. 2009. "Do Better Schools Lead to More Growth? Cognitive Skills, Economic Outcomes, and Causation." NBER working papers 14633, National Bureau of Economic Research.

Harbison, Ralph, and Eric Hanushek. 1992. Educational performance of the poor: Lessons from rural northeast Brazil. Oxford: Oxford University Press.

Hedges, Lany V., Richard Laine, and Rob Greenwald. 1994. "Does Money Matter? A MetaAnalysis of Studies of the Effects of Differential School Inputs on Student Outcomes." Education Researcher 23 (3): 5-14 (April).

Kaufmann, D., A. Kraay, and M. Mastruzzi. 2009. "Governance Matters VIII: Aggregate and Individual Governance Indicators, 1996-2008." World bank policy research working paper 4978, World Bank.

La Porta, Rafael, Florencio Lopez-de-Silanes, Andrei Shleifer, and Robert Vishny. 1999. "The Quality of Government." Journal of Law, Economics and Organization 15 (1): 222-79 (April).

Madeira, Ricardo. 2007. "The Effects of Decentralization on Schooling: Evidence From the Sao Paulo State Education Reform." Mimeo.

Mauro, Paolo. 1995. "Corruption and Growth." Quarterly Journal of Economics, no. 110:681-712. 
Menezes-Filho, Naercio A., and Elaine Pazello. 2007. "Do Teachers Wages Matter for Proficiency? Evidence from a Funding Reform in Brazil." Economics and Education Review 26 (6): 660-672.

Muralidharan, Karthik, and Venkatesh Sundararaman. 2011. "Teacher Performance Pay: Experimental Evidence from India." Journal of Political Economy 119 (1): 39-77.

Niehaus, Paul, and Sandip Sukhtankar. 2011. "The Marginal Rate of Corruption in Public Programs." UCSD, Mimeo.

Olken, Benjamin A. 2006. "Corruption and the costs of redistribution: Micro evidence from Indonesia." Journal of Public Economics 90 (4-5): 853-870 (May).

Pop-Eleches, Cristian, and Miguel Urquiola. 2011. "Going to a Better School: Effects and Behavioral Responses." Mimeo, Columbia University.

Reinikka, Ritva, and Jakob Svensson. 2004. "Local Capture: Evidence from a Central Government Transfer Program in Uganda." Quaterly Journal of Economics 119 (2): 679-705 (May).

- 2011. "The power of information in public services: Evidence from education in Uganda." Journal of Public Economics 95 (7-8): 956-966 (August).

Shleifer, Andrei, and Robert W. Vishny. 1993. "Corruption." Quarterly Journal of Economics 108 (3): 599-617 (August).

Svensson, Jakob. 2005. "Eight Questions about Corruption." Journal of Economic Perspectives 19 (3): 1942 (Summer).

Todd, Petra E., and Kenneth I. Wolpin. 2003. "On The Specification and Estimation of The Production Function for Cognitive Achievement." Economic Journal 113 (485): F3-F33 (February).

Transparência Brasil. 2005. "Brazil: The Hidden Cost of Decentralized Education." In Stealing the Future: Corruption in Classroom, edited by Bettina Meier and Michael Griffin. Berlin: Transparency International.

Treisman, Daniel. 2000. "The causes of corruption." Journal of Public Economics, vol. 76. 


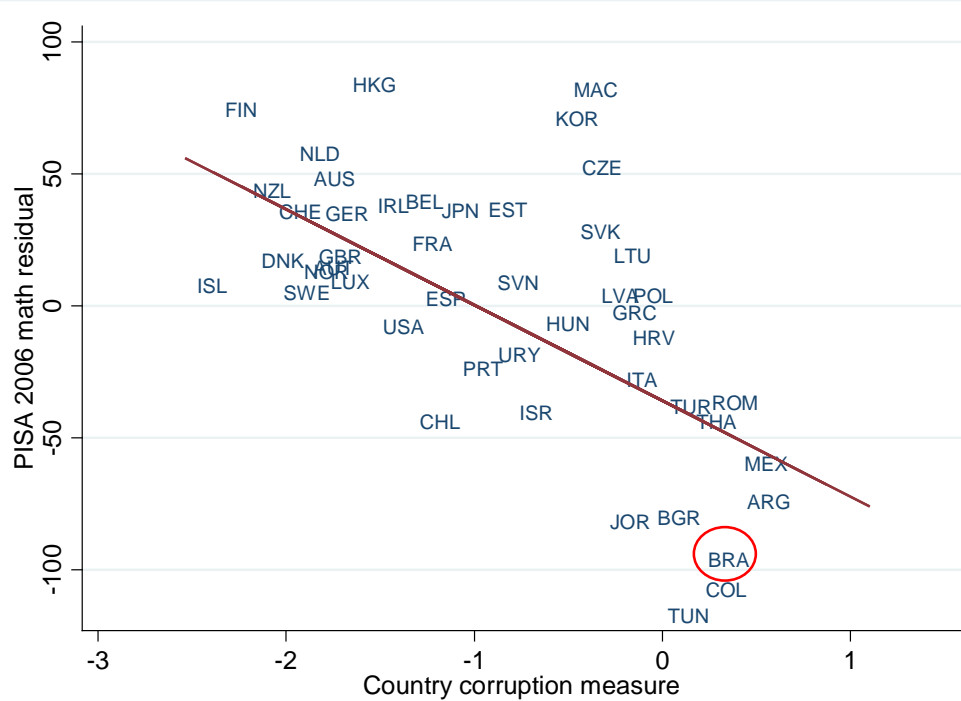

PANEL A: MATH

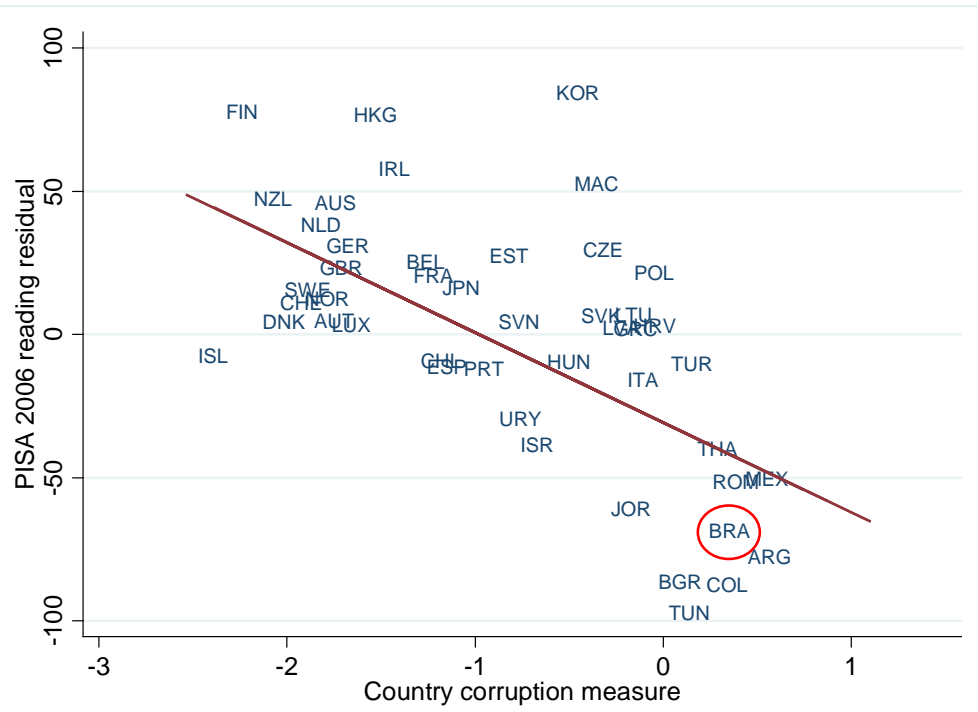

PANEL B: READING

FIGURE 1: TEST SCORES AND CORRUPTION

Notes: The scatter plots in panels A and B depict the relationship between the residuals from a regression of performance on the PISA exams in 2006 on expenditure on primary education per capita as a share of 2005 GDP per capita, and the World Bank corruption index (Kaufmann, Kraay, and Mastruzzi (2005)). The data used for these graphs can be found: http://www.pisa.oecd.org. 


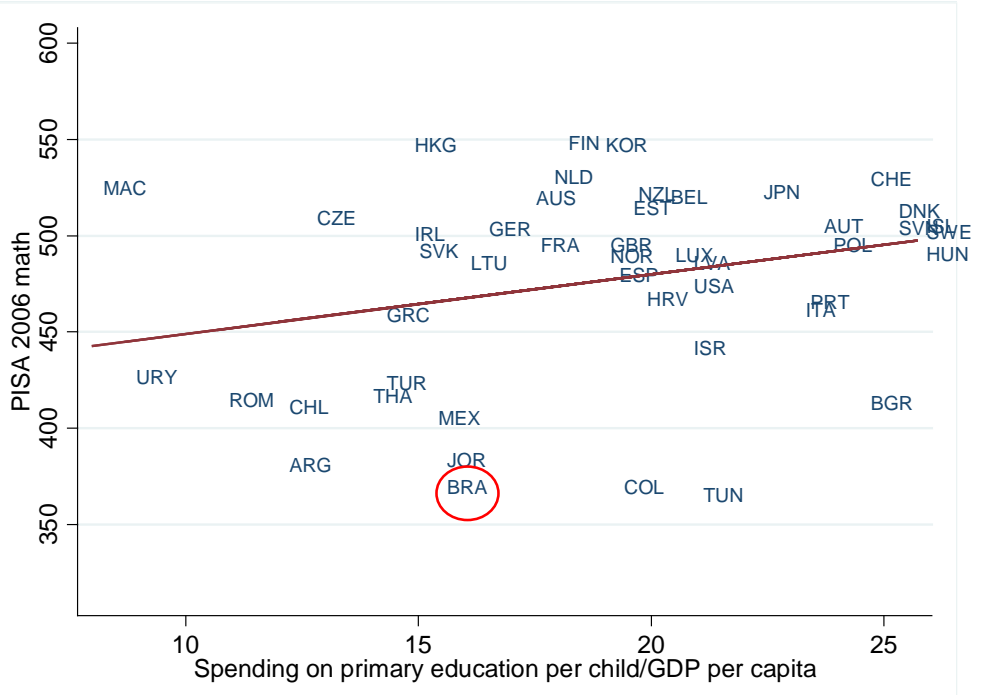

PANEL A: MATH

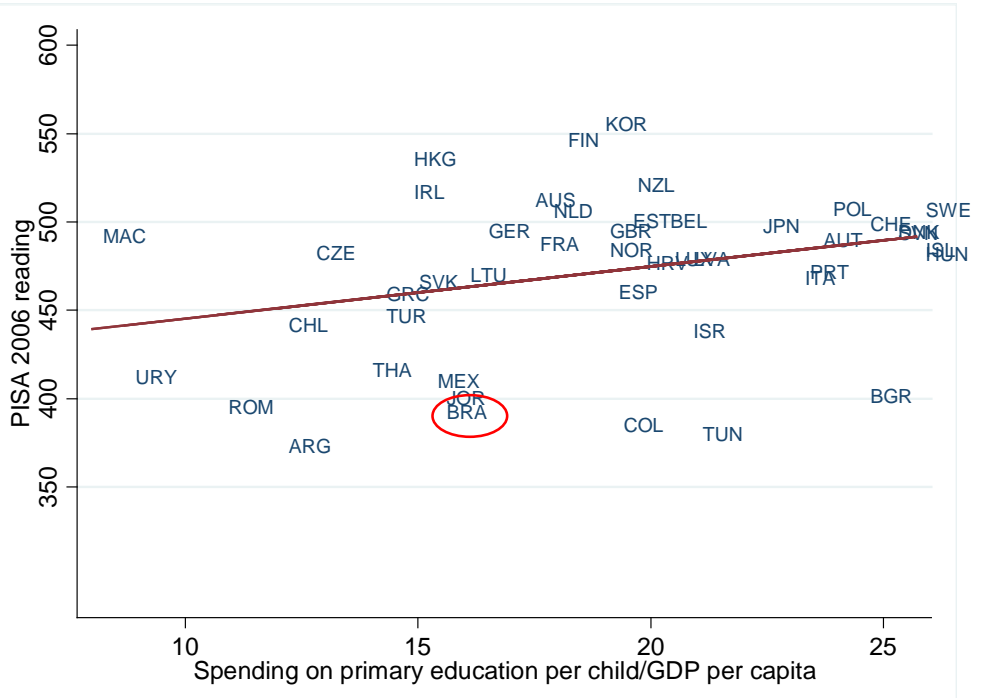

\section{PANEL B}

FIgURE 2: TEST SCORES AND SPENDING IN PRIMARY SCHOOL PER PUPIL IN 2005

Notes: The scatter plots in panels A and B depict the relationship between a country's performance on the PISA exams in 2006 and its expenditure on primary education per child as a share of GDP per capita in 2005. The data used for these graphs can be found: http://www.pisa.oecd.org. 


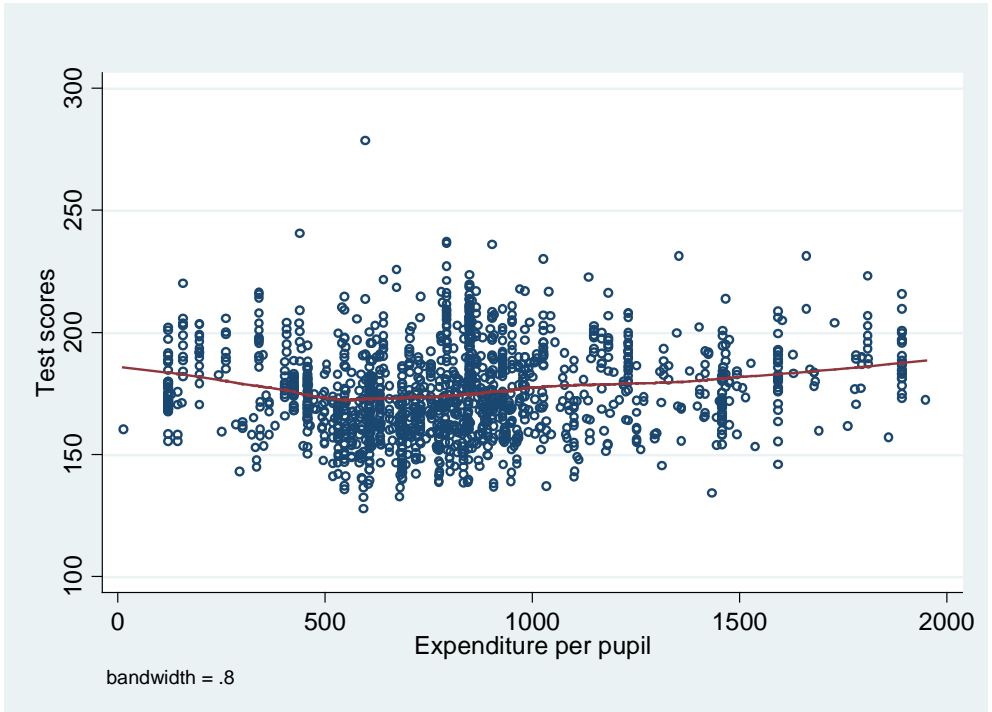

Panel A: Mathematics

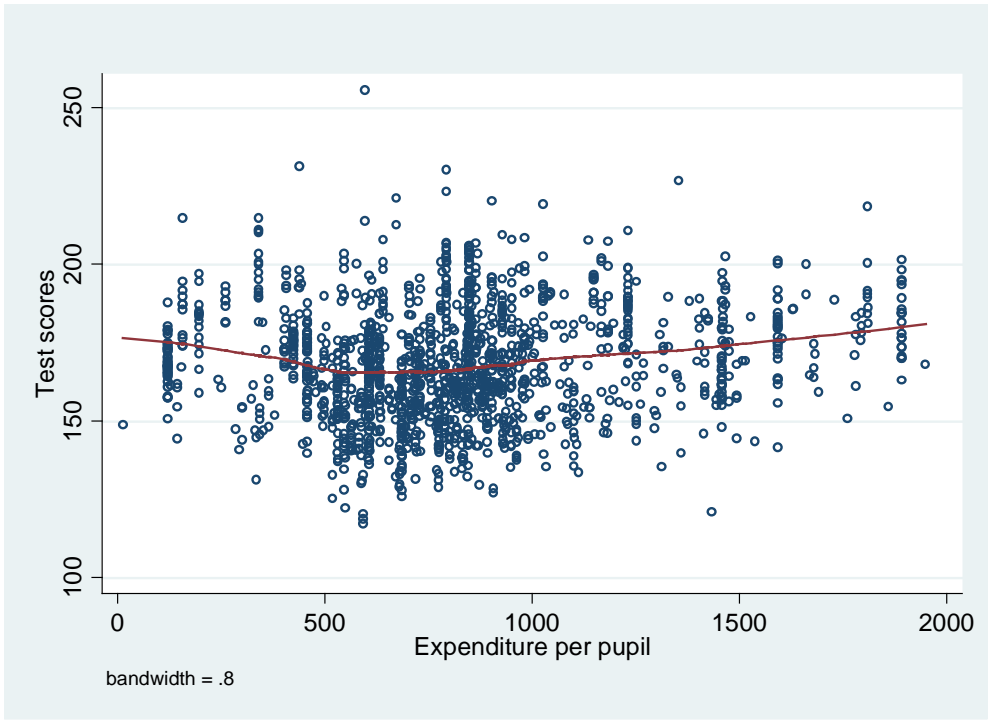

Panel B: Portuguese

FIgURE 3: TEST SCORES AND SPENDING IN PRIMARY SCHOOL PER PUPIL WITHIN BRAZIL

Notes: : The scatter plots in panels A and B depict the relationship between 2005 test scores on a national standardized exam for $4^{\text {th }}$ graders in Brazil and municipal expenditure on primary education per pupil in 2005. The line represents a nonparametric estimate of the relationship, with a bandwidth of 0.8. The data on test scores come from Prova Brasil and the data on expenditures come from Brazil’s national treasury. See the data appendix for more details. 


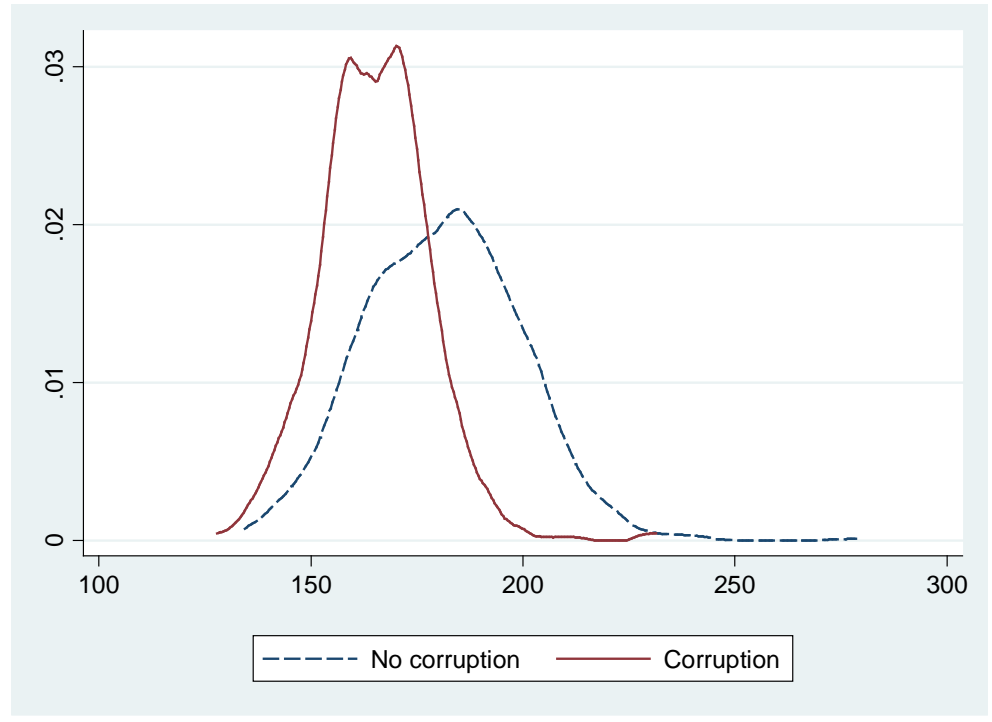

Panel A: Mathematics

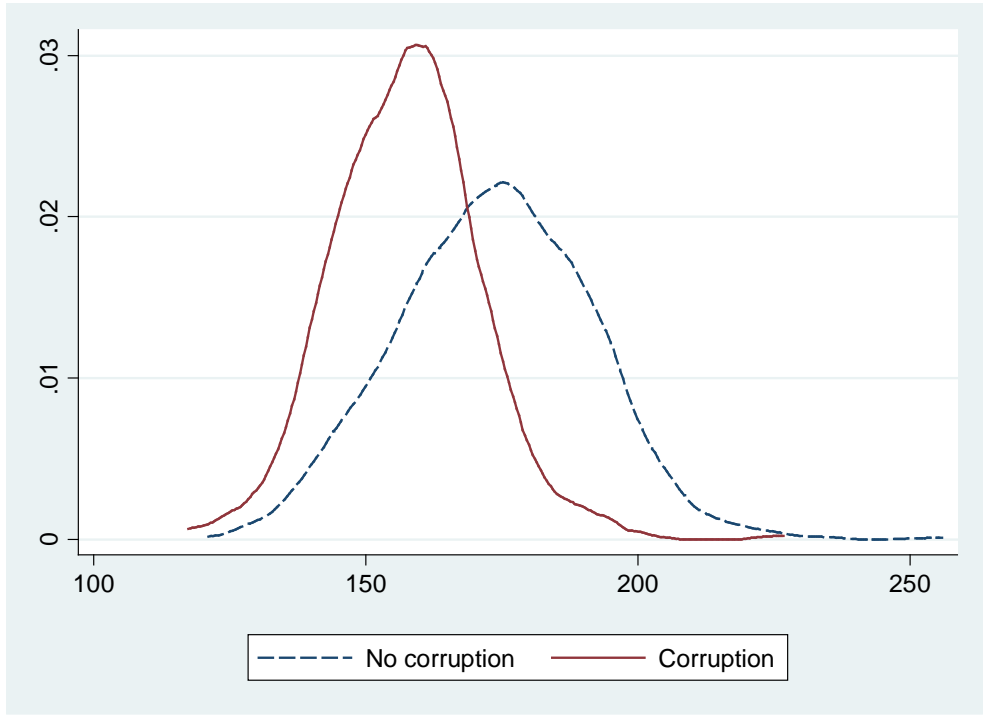

Panel B: Portuguese

Figure 4: Distribution OF TEST SCOREs FOR MATHEMATICS AND PORTUGUESE By CORRUPTION

Notes: Panels A and B display kernel densities of 2005 test scores aggregated at the school-level by subject matter. The densities were estimated separately depending on whether the school resided in a municipality where corruption was detected in education. The densities were estimated using the Epanechnikov kernel, with an optimally computed bandwidth. 

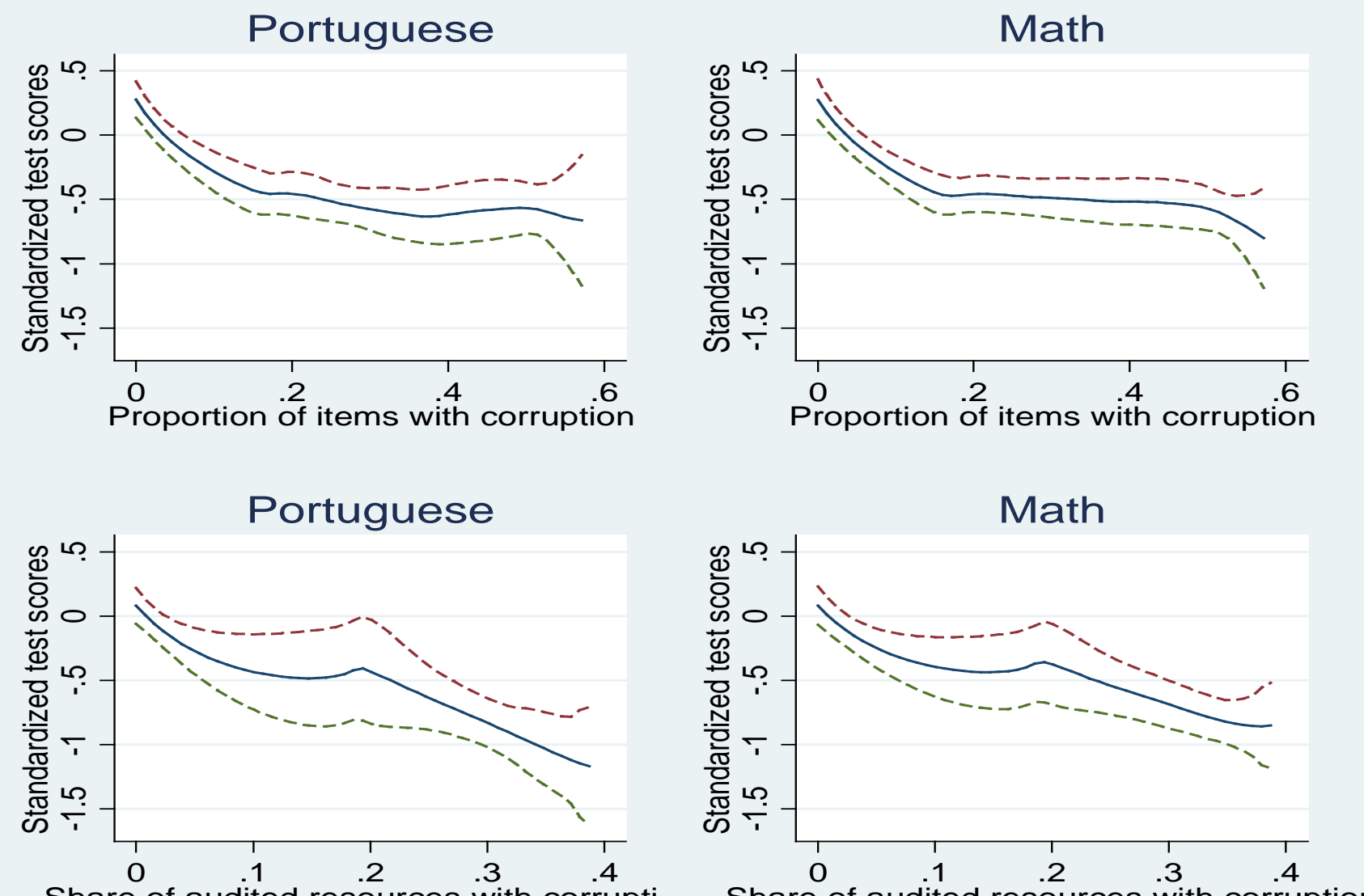

Share of audited resources with corrupti

FIGURE 5: ASSOCIATION BETWEEN TEST SCORES FOR MATHEMATICS AND PORTUGUESE AND CORRUPTION IN EDUCATION

Notes: Each graph shows the results of a locally weighted regression with a quartic Kernel (Fan, 1992). The dependent variable is the $4^{\text {th }}$ grade standardized test score for either Portuguese or Math and the independent variable is the respective measure of corruption (proportion of items found with corruption or share of audited resources found with corruption). The bandwidth is equal to one-third of the range of the independent variable. The lines in dashes show the 95 percent confidence intervals calculated with 100 bootstrapped replications where the standard error is clustered by municipality. The estimation dropped 5 outliers with extremely high corruption. 
TABLE 1: CORRUPTION IN THE EDUCATION SECTOR

\begin{tabular}{|c|c|c|c|c|c|c|}
\hline & $\mathrm{N}$ & mean & sd & p25 & p50 & $\mathrm{p} 75$ \\
\hline Proportion of municipalities with corruption in education & 365 & 0.35 & 0.48 & 0.00 & 0.00 & 1.00 \\
\hline Proportion of items in education found to be corrupt & 365 & 0.12 & 0.25 & 0.00 & 0.00 & 0.15 \\
\hline Proportion of items in education found to be corrupt conditional on some corruption & 128 & 0.35 & 0.32 & 0.13 & 0.25 & 0.50 \\
\hline Share of resources audited in education that were found to be corrupt & 365 & 0.03 & 0.12 & 0.00 & 0.00 & 0.01 \\
\hline Share of resources audited in education found to be corrupt conditional on some corruption & 128 & 0.08 & 0.19 & 0.00 & 0.03 & 0.07 \\
\hline Proportion of municipalities with corruption in some area other than education & 365 & 0.50 & 0.50 & 0.00 & 1.00 & 1.00 \\
\hline Proportion of items audited found to be associated with mismanagement & 365 & 2.00 & 1.83 & 0.75 & 1.46 & 2.71 \\
\hline Proportion of municipalities with corruption involving a school feeding program & 343 & 0.15 & 0.36 & 0.00 & 0.00 & 0.00 \\
\hline Proportion of municipalities with corruption involving teachers and school supplies & 305 & 0.28 & 0.45 & 0.00 & 0.00 & 1.00 \\
\hline Proportion of municipalities with corruption involving other aspects of education & 364 & 0.03 & 0.18 & 0.00 & 0.00 & 0.00 \\
\hline
\end{tabular}

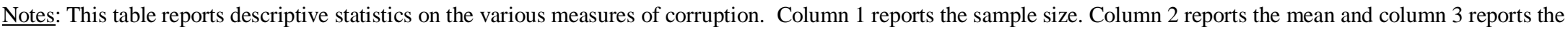
standard deviation. Columns $4-6$ report the $25^{\text {th }}, 50^{\text {th }}$, and $75^{\text {th }}$ percentiles of the distribution. The data used to compute these statistics come from the audit reports. 
TABLE 2: SUMMARY STATISTICS

\begin{tabular}{|c|c|c|c|c|c|c|}
\hline & $\mathrm{N}$ & mean & sd & p25 & p50 & p75 \\
\hline \multicolumn{7}{|l|}{ Panel A: Student characteristics } \\
\hline Standardized exam in Mathematics - 4th grade & 1488 & 175.80 & 18.25 & 162.23 & 174.01 & 188.22 \\
\hline Standardized exam in Portuguese - 4th grade & 1488 & 168.09 & 18.07 & 155.41 & 167.10 & 180.15 \\
\hline$\%$ males & 1488 & 0.50 & 0.09 & 0.45 & 0.50 & 0.56 \\
\hline$\%$ white & 1488 & 0.31 & 0.15 & 0.21 & 0.29 & 0.39 \\
\hline$\%$ of mothers with a high school degree & 1488 & 0.17 & 0.09 & 0.10 & 0.15 & 0.21 \\
\hline$\%$ of fathers with a high school degree & 1488 & 0.15 & 0.08 & 0.09 & 0.14 & 0.19 \\
\hline$\%$ children that live with both parents & 1488 & 0.61 & 0.12 & 0.54 & 0.62 & 0.70 \\
\hline$\%$ families with 6 or more inhabitants & 1488 & 0.26 & 0.13 & 0.17 & 0.24 & 0.34 \\
\hline$\%$ families with a home computer & 1488 & 0.15 & 0.10 & 0.08 & 0.13 & 0.20 \\
\hline$\%$ families with electricity at home & 1488 & 0.92 & 0.09 & 0.89 & 0.94 & 0.97 \\
\hline$\%$ families with running water at home & 1488 & 0.84 & 0.14 & 0.79 & 0.88 & 0.93 \\
\hline$\%$ of children who are 8 years old or younger & 1488 & 0.01 & 0.02 & 0.00 & 0.00 & 0.02 \\
\hline$\%$ of children who are 9 years old & 1488 & 0.05 & 0.05 & 0.01 & 0.04 & 0.07 \\
\hline$\%$ of children who are 10 years old & 1488 & 0.36 & 0.18 & 0.22 & 0.35 & 0.49 \\
\hline$\%$ of children who are 11 years old & 1488 & 0.25 & 0.10 & 0.18 & 0.24 & 0.31 \\
\hline$\%$ of children who are 12 years old & 1488 & 0.12 & 0.07 & 0.07 & 0.11 & 0.16 \\
\hline \multicolumn{7}{|l|}{ Panel B: School Characteristics } \\
\hline Dropout rates & 1488 & 0.04 & 0.07 & 0.00 & 0.02 & 0.06 \\
\hline Failure rates & 1488 & 0.10 & 0.09 & 0.03 & 0.09 & 0.16 \\
\hline$\%$ of teachers with a teaching credential & 1488 & 0.43 & 0.36 & 0.05 & 0.42 & 0.75 \\
\hline School has a computer lab & 1488 & 0.19 & 0.39 & 0.00 & 0.00 & 0.00 \\
\hline School has a science lab & 1488 & 0.04 & 0.19 & 0.00 & 0.00 & 0.00 \\
\hline School has sanitation & 1488 & 0.03 & 0.17 & 0.00 & 0.00 & 0.00 \\
\hline \multicolumn{7}{|l|}{ Director's survey } \\
\hline Lack of financial resources is a serious concern & 1488 & 0.55 & 0.50 & 0.00 & 1.00 & 1.00 \\
\hline Lack of schooling supplies is a serious concern & 1488 & 0.40 & 0.49 & 0.00 & 0.00 & 1.00 \\
\hline Lack of teachers is a serious concern & 1488 & 0.23 & 0.42 & 0.00 & 0.00 & 0.00 \\
\hline Disciplinary problems is a serious concern & 1488 & 0.63 & 0.48 & 0.00 & 1.00 & 1.00 \\
\hline Training courses are provided to teachers & 1488 & 0.49 & 0.50 & 0.00 & 0.00 & 1.00 \\
\hline \multicolumn{7}{|l|}{ Teacher's survey } \\
\hline Lack of financial resources is a serious concern & 1488 & 0.56 & 0.50 & 0.00 & 1.00 & 1.00 \\
\hline Lack of schooling supplies is a serious concern & 1488 & 0.51 & 0.50 & 0.00 & 1.00 & 1.00 \\
\hline Lack of teachers is a serious concern & 1488 & 0.26 & 0.44 & 0.00 & 0.00 & 1.00 \\
\hline Disciplinary problems is a serious concern & 1488 & 0.63 & 0.48 & 0.00 & 1.00 & 1.00 \\
\hline
\end{tabular}

Notes: This table reports descriptive statistics for the variables used in the analysis. Column 1 reports the sample size. Column 2 reports the mean and column 3 reports the standard deviation. Columns $4-6$ report the $25^{\text {th }}$, $50^{\text {th }}$, and $75^{\text {th }}$ percentiles of the distribution. The variables presented in Panels A and B are computed for the 1488 schools that reside in the 365 municipalities for which information on corruption exists. 
TABLE 2: SUMMARY STATISTICS (CONTINUED...)

\begin{tabular}{|c|c|c|c|c|c|c|}
\hline & $\mathrm{N}$ & mean & sd & p25 & p50 & p75 \\
\hline \multicolumn{7}{|l|}{ Panel C: Municipal Characteristics } \\
\hline \% population urban & 365 & 0.61 & 0.23 & 0.44 & 0.62 & 0.80 \\
\hline Gini & 365 & 0.57 & 0.06 & 0.54 & 0.57 & 0.61 \\
\hline GDP per capita & 365 & 8707.74 & 22821.08 & 2545.43 & 4678.03 & 8544.47 \\
\hline Expenditure in primary school per child & 365 & 942.20 & 487.67 & 656.48 & 856.68 & 1106.40 \\
\hline Dropout rates among private schools & 188 & 0.01 & 0.03 & 0.00 & 0.00 & 0.00 \\
\hline Failure rates among private schools & 188 & 0.02 & 0.04 & 0.00 & 0.00 & 0.02 \\
\hline Election is held for principal & 365 & 0.10 & 0.30 & 0.00 & 0.00 & 0.00 \\
\hline Average number of state schools that elect its principal & 365 & 0.43 & 1.25 & 0.00 & 0.00 & 0.00 \\
\hline Average number of state schools in the municipality & 365 & 1.68 & 3.31 & 0.00 & 1.00 & 2.00 \\
\hline PTA is active in the municipality & 365 & 0.48 & 0.50 & 0.00 & 0.00 & 1.00 \\
\hline Municipality has a intergovernmental consortium & 365 & 0.26 & 0.44 & 0.00 & 0.00 & 1.00 \\
\hline Municipality has an education council & 365 & 0.69 & 0.46 & 0.00 & 1.00 & 1.00 \\
\hline Schools receive support from private sector & 365 & 0.07 & 0.25 & 0.00 & 0.00 & 0.00 \\
\hline Municipality uses participatory budgeting & 365 & 0.71 & 0.45 & 0.00 & 1.00 & 1.00 \\
\hline The community helps in the maintenance of the school & 365 & 0.15 & 0.36 & 0.00 & 0.00 & 0.00 \\
\hline The school participated in an awareness campaign for the community & 365 & 0.41 & 0.49 & 0.00 & 0.00 & 1.00 \\
\hline
\end{tabular}

Notes: This table reports descriptive statistics for the variables used in the analysis. Column 1 reports the sample size. Column 2 reports the mean and column 3 reports the standard deviation. Columns $4-6$ report the $25^{\text {th }}$, $50^{\text {th }}$, and $75^{\text {th }}$ percentiles of the distribution. The variables presented in Panels A and B are computed for the 1488 schools that reside in the 365 municipalities for which information on corruption exists. 
TABLE 3: DETERMINANTS OF CORRUPTION IN EDUCATION

\begin{tabular}{|c|c|c|c|c|c|c|}
\hline \multirow[t]{3}{*}{ Dependent variable: } & \multicolumn{2}{|c|}{$\begin{array}{l}\text { Corruption in } \\
\text { education }\end{array}$} & \multicolumn{2}{|c|}{$\begin{array}{l}\text { Proportion of items } \\
\text { with corruption in } \\
\text { education }\end{array}$} & \multicolumn{2}{|c|}{$\begin{array}{l}\text { Share of audited } \\
\text { resources with } \\
\text { corruption in } \\
\text { education }\end{array}$} \\
\hline & OLS & Probit & OLS & Tobit & OLS & Tobit \\
\hline & $(1)$ & $(2)$ & $(3)$ & $(4)$ & $(5)$ & $(6)$ \\
\hline \multicolumn{7}{|l|}{ School finance: } \\
\hline$\%$ education revenue from FUNDEF transfers & $\begin{array}{c}0.501 \\
{[0.200]^{* *}}\end{array}$ & $\begin{array}{c}0.574 \\
{[0.277]^{* *}}\end{array}$ & $\begin{array}{c}0.195 \\
{[0.096]^{* *}}\end{array}$ & $\begin{array}{c}0.209 \\
{[0.103]^{* *}}\end{array}$ & $\begin{array}{c}0.036 \\
{[0.024]}\end{array}$ & $\begin{array}{c}0.044 \\
{[0.022]^{* *}}\end{array}$ \\
\hline \multicolumn{7}{|l|}{ Socio-economic characteristics } \\
\hline Share of urban population & $\begin{array}{c}-0.413 \\
{[0.135]^{* * *}}\end{array}$ & $\begin{array}{c}-0.417 \\
{[0.145]^{* * *}}\end{array}$ & $\begin{array}{c}-0.224 \\
{[0.075]^{* * *}}\end{array}$ & $\begin{array}{c}-0.178 \\
{[0.055]^{* * *}}\end{array}$ & $\begin{array}{l}-0.006 \\
* \quad[0.010]\end{array}$ & $\begin{array}{l}-0.017 \\
{[0.011]}\end{array}$ \\
\hline Gini coefficient & $\begin{array}{c}0.745 \\
{[0.417]^{*}}\end{array}$ & $\begin{array}{c}0.883 \\
{[0.456]^{*}}\end{array}$ & $\begin{array}{c}0.286 \\
{[0.255]}\end{array}$ & $\begin{array}{c}0.326 \\
{[0.178]^{*}}\end{array}$ & $\begin{array}{c}0.055 \\
{[0.044]}\end{array}$ & $\begin{array}{c}0.061 \\
{[0.037]}\end{array}$ \\
\hline Log GDP per capita & $\begin{array}{l}-0.041 \\
{[0.037]}\end{array}$ & $\begin{array}{c}-0.034 \\
{[0.040]}\end{array}$ & $\begin{array}{c}0.026 \\
{[0.033]}\end{array}$ & $\begin{array}{c}0.003 \\
{[0.013]}\end{array}$ & $\begin{array}{c}-0.011 \\
{[0.004]^{* *}}\end{array}$ & $\begin{array}{c}-0.006 \\
{ }^{k}[0.003]^{* *}\end{array}$ \\
\hline Log population & $\begin{array}{c}0.043 \\
{[0.033]}\end{array}$ & $\begin{array}{c}0.050 \\
{[0.039]}\end{array}$ & $\begin{array}{c}0.015 \\
{[0.020]}\end{array}$ & $\begin{array}{c}0.016 \\
{[0.015]}\end{array}$ & $\begin{array}{c}0.001 \\
{[0.003]}\end{array}$ & $\begin{array}{c}0.002 \\
{[0.003]}\end{array}$ \\
\hline \multicolumn{7}{|l|}{ School institutions } \\
\hline Share of schools with elections & $\begin{array}{c}-0.017 \\
{[0.010]^{*}}\end{array}$ & $\begin{array}{c}-0.089 \\
{[0.037]^{* *}}\end{array}$ & $\begin{array}{c}-0.006 \\
{[0.005]}\end{array}$ & $\begin{array}{c}-0.033 \\
{[0.015]^{* *}}\end{array}$ & $\begin{array}{l}-0.001 \\
{[0.001]}\end{array}$ & $\begin{array}{c}-0.007 \\
{[0.003]^{* *}}\end{array}$ \\
\hline Share of schools with a PTA & $\begin{array}{c}0.000 \\
{[0.011]}\end{array}$ & $\begin{array}{c}0.009 \\
{[0.014]}\end{array}$ & $\begin{array}{c}0.002 \\
{[0.006]}\end{array}$ & $\begin{array}{c}0.006 \\
{[0.006]}\end{array}$ & $\begin{array}{l}-0.001 \\
{[0.002]}\end{array}$ & $\begin{array}{c}0.000 \\
{[0.001]}\end{array}$ \\
\hline \% schools community helps in maintenance & $\begin{array}{l}-0.011 \\
{[0.021]}\end{array}$ & $\begin{array}{l}-0.033 \\
{[0.030]}\end{array}$ & $\begin{array}{c}-0.021 \\
{[0.016]}\end{array}$ & $\begin{array}{c}-0.025 \\
{[0.012]^{* *}}\end{array}$ & $\begin{array}{l}-0.001 \\
{[0.003]}\end{array}$ & $\begin{array}{l}-0.002 \\
{[0.002]}\end{array}$ \\
\hline$\%$ schools participate in an awareness community & $\begin{array}{cc}y & 0.014 \\
& {[0.019]}\end{array}$ & $\begin{array}{c}0.014 \\
{[0.023]}\end{array}$ & $\begin{array}{c}0.018 \\
{[0.017]}\end{array}$ & $\begin{array}{c}0.012 \\
{[0.010]}\end{array}$ & $\begin{array}{c}0.003 \\
{[0.003]}\end{array}$ & $\begin{array}{c}0.002 \\
{[0.002]}\end{array}$ \\
\hline \multicolumn{7}{|l|}{ Preferences towards education } \\
\hline Log spending primary education per kid $(\times 100)$ & $\begin{array}{l}-7.632 \\
{[5.004]}\end{array}$ & $\begin{array}{c}-9.502 \\
{[5.291]^{*}}\end{array}$ & $\begin{array}{l}-0.318 \\
{[2.680]}\end{array}$ & $\begin{array}{l}-2.125 \\
{[1.961]}\end{array}$ & $\begin{array}{c}0.004 \\
{[0.561]}\end{array}$ & $\begin{array}{l}-0.331 \\
{[0.401]}\end{array}$ \\
\hline Intergovernmental consortium in education & $\begin{array}{c}0.052 \\
{[0.057]}\end{array}$ & $\begin{array}{c}0.065 \\
{[0.063]}\end{array}$ & $\begin{array}{c}0.014 \\
{[0.032]}\end{array}$ & $\begin{array}{c}0.018 \\
{[0.024]}\end{array}$ & $\begin{array}{c}0.007 \\
{[0.007]}\end{array}$ & $\begin{array}{c}0.006 \\
{[0.005]}\end{array}$ \\
\hline Education council exists & $\begin{array}{c}-0.093 \\
{[0.056]^{*}}\end{array}$ & $\begin{array}{c}-0.103 \\
{[0.058]^{*}}\end{array}$ & $\begin{array}{c}-0.073 \\
{[0.031]^{* *}}\end{array}$ & $\begin{array}{c}-0.055 \\
{[0.024]^{* *}}\end{array}$ & $\begin{array}{l}-0.004 \\
{[0.007]}\end{array}$ & $\begin{array}{c}-0.009 \\
{[0.005]^{*}}\end{array}$ \\
\hline Mayor is a male & $\begin{array}{l}-0.142 \\
{[0.095]}\end{array}$ & $\begin{array}{l}-0.161 \\
{[0.107]}\end{array}$ & $\begin{array}{c}-0.122 \\
{[0.080]}\end{array}$ & $\begin{array}{c}-0.094 \\
{[0.056]^{*}}\end{array}$ & $\begin{array}{l}-0.002 \\
{[0.010]}\end{array}$ & $\begin{array}{l}-0.008 \\
{[0.009]}\end{array}$ \\
\hline Mayor has a college degree & $\begin{array}{c}-0.136 \\
{[0.051]^{* * *}}\end{array}$ & $\begin{array}{c}-0.148 \\
{[0.053]^{* * *}}\end{array}$ & $\begin{array}{c}-0.036 \\
{[0.030]}\end{array}$ & $\begin{array}{c}-0.050 \\
{[0.021]^{* *}}\end{array}$ & $\begin{array}{c}-0.004 \\
{[0.006]}\end{array}$ & $\begin{array}{c}-0.007 \\
{[0.004]^{*}}\end{array}$ \\
\hline Number of observations & 366 & 366 & 366 & 366 & 361 & 361 \\
\hline R-squared & 0.18 & & 0.11 & & 0.06 & \\
\hline Pseudo R-squared & & 0.17 & & 0.15 & & 0.69 \\
\hline
\end{tabular}

Notes: This table reports the association between municipal characteristics and different measures of corruption in education. Column (1), (3) and (5) present OLS results, while columns (2), (4) and (6) present the marginal effects of non-linear models that account for the discrete or censured dependent variable. The dependent variable used in each regression is listed at the top of each column. All regressions exclude municipalities that report zero revenues from the FUNDEF program. The regressions shown in columns (5) and (6) exclude municipalities where the estimated share of corruption is above 1. Robust standard errors are displayed in brackets. Significantly different than zero at $99(* * *), 95(* *), 90(*)$ percent confidence. 


\section{TABLE 4: THE EFFECTS OF CORRUPTION ON SCHOOLING OUTCOMES}

\begin{tabular}{|c|c|c|c|c|c|c|c|c|}
\hline \multirow[t]{2}{*}{ Dependent variable: } & \multicolumn{2}{|c|}{ Mathematics } & \multicolumn{2}{|c|}{ Portuguese } & \multicolumn{2}{|c|}{ Dropout rates } & \multicolumn{2}{|c|}{ Failure rates } \\
\hline & (1) & (2) & (3) & $(4)$ & $(5)$ & (6) & (7) & (8) \\
\hline \multicolumn{9}{|l|}{ Panel A: } \\
\hline 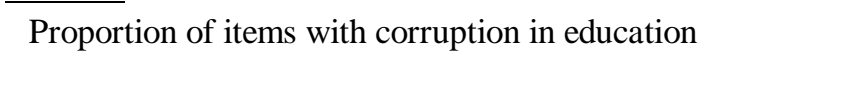 & $\begin{array}{c}-0.323 \\
{[0.069]^{* * *}}\end{array}$ & $\begin{array}{c}-0.315 \\
{[0.078]^{* * *}}\end{array}$ & $\begin{array}{c}-0.356 \\
{[0.068]^{* * *}}\end{array}$ & $\begin{array}{c}-0.34 \\
{[0.069]^{* * *}}\end{array}$ & $\begin{array}{c}0.021 \\
{[0.010]^{* *}}\end{array}$ & $\begin{array}{c}0.019 \\
{[0.008]^{* *}}\end{array}$ & $\begin{array}{c}0.019 \\
{[0.006]^{* * *}}\end{array}$ & $\begin{array}{c}0.018 \\
{[0.006]^{* * *}}\end{array}$ \\
\hline R-squared & 0.49 & 0.52 & 0.55 & 0.59 & 0.26 & 0.29 & 0.15 & 0.16 \\
\hline \multicolumn{9}{|l|}{ Panel B: } \\
\hline Share of audited resources with corruption in education & $\begin{array}{c}-0.722 \\
{[0.372]^{*}}\end{array}$ & $\begin{array}{l}-0.447 \\
{[0.320]}\end{array}$ & $\begin{array}{c}-0.9 \\
{[0.413]^{* *}}\end{array}$ & $\begin{array}{l}-0.583 \\
{[0.365]}\end{array}$ & $\begin{array}{c}0.048 \\
{[0.016]^{* * *}}\end{array}$ & $\begin{array}{c}0.028 \\
{[0.019]}\end{array}$ & $\begin{array}{c}0.029 \\
{[0.023]}\end{array}$ & $\begin{array}{c}0.022 \\
{[0.023]}\end{array}$ \\
\hline R-squared & 0.49 & 0.52 & 0.54 & 0.58 & 0.26 & 0.28 & 0.15 & 0.15 \\
\hline \multicolumn{9}{|l|}{ Panel C: } \\
\hline$\overline{\text { Corruption in education }}$ & $\begin{array}{c}-0.356 \\
{[0.076]^{* * *}}\end{array}$ & $\begin{array}{c}-0.29 \\
{[0.076]^{* * *}}\end{array}$ & $\begin{array}{c}-0.357 \\
{[0.070]^{* * *}}\end{array}$ & $\begin{array}{c}-0.277 \\
{[0.073]^{* * *}}\end{array}$ & $\begin{array}{c}0.029 \\
{[0.005]^{* * *}}\end{array}$ & $\begin{array}{c}0.024 \\
{[0.005]^{* * *}}\end{array}$ & $\begin{array}{c}0.019 \\
{[0.008]^{* *}}\end{array}$ & $\begin{array}{c}0.018 \\
{[0.008]^{* *}}\end{array}$ \\
\hline R-squared & 0.51 & 0.53 & 0.56 & 0.59 & 0.29 & 0.31 & 0.16 & 0.16 \\
\hline $\begin{array}{l}\text { Student characteristics } \\
\text { Municipal characteristics }\end{array}$ & $\begin{array}{l}\text { Yes } \\
\text { No }\end{array}$ & $\begin{array}{l}\text { Yes } \\
\text { Yes }\end{array}$ & $\begin{array}{l}\text { Yes } \\
\text { No }\end{array}$ & $\begin{array}{l}\text { Yes } \\
\text { Yes }\end{array}$ & $\begin{array}{l}\text { Yes } \\
\text { No }\end{array}$ & $\begin{array}{l}\text { Yes } \\
\text { Yes }\end{array}$ & $\begin{array}{l}\text { Yes } \\
\text { No }\end{array}$ & $\begin{array}{l}\text { Yes } \\
\text { Yes }\end{array}$ \\
\hline
\end{tabular}

Notes: This table reports the effects of corruption on various education outcomes. Each column presents the results of an OLS regression where the dependent variable is listed at the top of each column. For the results reported in Panels A, C, and D, the number of observations is 1488 schools. Whereas, for Panel B, the number of observations is 1479 , due to missing values in the amount of resources audited. Student characteristics included proportion of male children, proportion of white children, the schooling of the mother, schooling of the father, the proportion of kids with both parents living at home, family size, proportion of households with a computer, proportion of families with running water, proportion of families with electricity, and age dummies. Municipal characteristics included share of population that resides in urban areas, Gini coefficient, Log GDP per capita in 2004, and log population. Robust standard errors clustered at the municipality are displayed in brackets. Significantly different than zero at $99(* * *)$, $95(* *)$, $90(*)$ percent confidence. 
TABLE 5: THE EFFECTS OF CORRUPTION ON SCHOOLING OUTCOMES - ROBUSTNESS

\begin{tabular}{|c|c|c|c|c|c|c|c|c|}
\hline \multirow[t]{2}{*}{ Dependent variable: } & \multicolumn{2}{|c|}{ Mathematics } & \multicolumn{2}{|c|}{ Portuguese } & \multicolumn{2}{|c|}{ Dropout rates } & \multicolumn{2}{|c|}{ Failure rates } \\
\hline & (1) & (2) & (3) & (4) & (5) & (6) & (7) & (8) \\
\hline \multirow[t]{2}{*}{ Corruption in education } & -0.286 & -0.283 & -0.264 & -0.277 & 0.027 & 0.027 & 0.018 & 0.022 \\
\hline & {$[0.076]^{* * *}$} & {$[0.080]^{* * *}$} & {$[0.071]^{* * *}$} & {$[0.070]^{* * *}$} & {$[0.005]^{* * *}$} & {$[0.005]^{* * *}$} & {$[0.009]^{* *}$} & {$[0.009]^{* *}$} \\
\hline \multicolumn{9}{|l|}{$\underline{\text { Local institutional quality }}$} \\
\hline \multirow[t]{2}{*}{ Corruption in other sectors } & -0.199 & -0.185 & -0.162 & -0.141 & 0.007 & 0.006 & 0.001 & 0.001 \\
\hline & {$[0.068]^{* * *}$} & {$[0.068]^{* * *}$} & {$[0.064]^{* *}$} & {$[0.063]^{* *}$} & {$[0.004]^{*}$} & [0.004] & [0.007] & [0.007] \\
\hline \multirow[t]{2}{*}{ Judiciary district } & 0.133 & 0.146 & 0.179 & 0.202 & -0.004 & -0.007 & -0.006 & -0.003 \\
\hline & [0.093] & {$[0.092]$} & {$[0.083]^{* *}$} & {$[0.084]^{* *}$} & {$[0.005]$} & {$[0.005]$} & {$[0.007]$} & {$[0.008]$} \\
\hline \multirow[t]{2}{*}{ Share of council that supports the mayor } & -0.178 & -0.145 & -0.133 & -0.107 & -0.015 & -0.014 & -0.022 & -0.028 \\
\hline & {$[0.190]$} & [0.187] & {$[0.168]$} & {$[0.162]$} & {$[0.012]$} & {$[0.012]$} & {$[0.020]$} & {$[0.019]$} \\
\hline \multirow{2}{*}{ Practices participatory budgeting } & 0.024 & -0.005 & 0.074 & 0.044 & 0.009 & 0.009 & -0.001 & 0.001 \\
\hline & {$[0.079]$} & {$[0.076]$} & {$[0.071]$} & {$[0.067]$} & {$[0.005]^{*}$} & {$[0.005]^{*}$} & {$[0.010]$} & {$[0.010]$} \\
\hline \multicolumn{9}{|l|}{ School institutions } \\
\hline \multirow[t]{2}{*}{ School elects the principal } & & 0.136 & & 0.081 & & 0.004 & & 0.005 \\
\hline & & {$[0.079]^{*}$} & & {$[0.062]$} & & {$[0.004]$} & & {$[0.008]$} \\
\hline \multirow[t]{2}{*}{ School has active PTA } & & 0.014 & & 0.057 & & -0.003 & & -0.001 \\
\hline & & {$[0.045]$} & & {$[0.036]$} & & {$[0.003]$} & & [0.005] \\
\hline \multirow[t]{2}{*}{ School receives help from community } & & 0.056 & & 0.035 & & -0.003 & & -0.002 \\
\hline & & {$[0.050]$} & & {$[0.041]$} & & [0.003] & & {$[0.006]$} \\
\hline \multirow[t]{2}{*}{ School participates in community awareness campaigns } & & 0.012 & & 0.005 & & -0.001 & & 0.006 \\
\hline & & {$[0.035]$} & & [0.035] & & [0.003] & & {$[0.004]$} \\
\hline \multicolumn{9}{|l|}{ Preferences towards education } \\
\hline \multirow[t]{2}{*}{ Municipality has an intergovernment consortium in education } & & 0.136 & & 0.161 & & -0.004 & & 0.001 \\
\hline & & {$[0.078]^{*}$} & & {$[0.067]^{* *}$} & & {$[0.005]$} & & {$[0.008]$} \\
\hline \multirow[t]{2}{*}{ Education council exists } & & -0.031 & & -0.002 & & 0.003 & & 0.002 \\
\hline & & [0.077] & & [0.064] & & {$[0.005]$} & & [0.007] \\
\hline \multirow[t]{2}{*}{ Mayor is a male } & & 0.082 & & 0.02 & & 0.011 & & -0.01 \\
\hline & & {$[0.124]$} & & [0.125] & & {$[0.008]$} & & {$[0.014]$} \\
\hline \multirow[t]{2}{*}{ Mayor has a college degree } & & 0.07 & & 0.062 & & -0.008 & & 0.015 \\
\hline & & {$[0.072]$} & & {$[0.066]$} & & {$[0.005]$} & & {$[0.008]^{*}$} \\
\hline Student and municipal characteristics & Yes & Yes & Yes & Yes & Yes & Yes & Yes & Yes \\
\hline Number of schools & 1488 & 1468 & 1488 & 1468 & 1488 & 1468 & 1488 & 1468 \\
\hline R-squared & 0.54 & 0.55 & 0.6 & 0.61 & 0.31 & 0.32 & 0.16 & 0.17 \\
\hline
\end{tabular}

Notes: This table reports the effects of corruption on various education outcomes. Each column presents the results of an OLS regression where the dependent variable is listed at the top of each column. Our measure of corruption is an indicator for whether corruption was detected in education. Our measure of other corruption is an indicator for whether corruption was detected in sectors other than education. Student characteristics included proportion of male children, proportion of white children, the schooling of the mother, schooling of the father, the proportion of kids with both parents living at home, family size, proportion of households with a computer, proportion of families with running water, proportion of families with electricity, and age dummies. Municipal characteristics included share of population that resides in urban areas, Gini coefficient, GDP per capita in 2004, and expenditure per child in primary school. Robust standard errors clustered at the municipality are displayed in brackets. Significantly different than zero at 99 (***), 95 $(* *), 90\left(^{*}\right)$ percent confidence. 


\section{TABLE 6: PRIVATE SCHOOLS}

\begin{tabular}{|c|c|c|c|c|c|c|c|}
\hline Dependent variable: & $\begin{array}{l}\text { Dropout rates for } \\
\text { private schools } \\
\text { (1) }\end{array}$ & $\begin{array}{l}\text { Failure rates for } \\
\text { private schools } \\
\text { (2) }\end{array}$ & $\begin{array}{l}\text { Share of students } \\
\text { enrolled in a } \\
\text { private school } \\
\text { (3) }\end{array}$ & $\begin{array}{c}\text { Mathematics } \\
\text { (4) }\end{array}$ & $\begin{array}{c}\text { Portuguese } \\
\text { (5) }\end{array}$ & $\begin{array}{c}\text { Dropout rates } \\
(6) \\
\end{array}$ & $\begin{array}{c}\text { Failure rates } \\
(7) \\
\end{array}$ \\
\hline $\begin{array}{l}\text { Corruption in education } \\
\text { Corruption in education } \times \text { Municipality has a private school }\end{array}$ & $\begin{array}{c}-0.005 \\
{[0.003]}\end{array}$ & $\begin{array}{c}-0.008 \\
{[0.006]}\end{array}$ & $\begin{array}{c}0.004 \\
{[0.009]}\end{array}$ & $\begin{array}{c}-0.28 \\
{[0.101]^{* * *}} \\
0.003 \\
{[0.100]}\end{array}$ & $\begin{array}{c}-0.249 \\
{[0.098]^{* *}} \\
-0.017 \\
{[0.097]}\end{array}$ & $\begin{array}{c}0.023 \\
{[0.006]^{* * *}} \\
0.002 \\
{[0.008]}\end{array}$ & $\begin{array}{c}0.019 \\
{[0.013]} \\
-0.003 \\
{[0.012]}\end{array}$ \\
\hline $\begin{array}{l}\text { Student characteristics } \\
\text { Municipal characteristics } \\
\text { Number of schools } \\
\text { R-squared }\end{array}$ & $\begin{array}{c}\text { Yes } \\
\text { Yes } \\
1185 \\
0.07\end{array}$ & $\begin{array}{c}\text { Yes } \\
\text { Yes } \\
1185 \\
0.14\end{array}$ & $\begin{array}{l}\text { No } \\
\text { Yes } \\
331 \\
0.04\end{array}$ & $\begin{array}{c}\text { Yes } \\
\text { Yes } \\
1488 \\
0.53\end{array}$ & $\begin{array}{c}\text { Yes } \\
\text { Yes } \\
1488 \\
0.59\end{array}$ & $\begin{array}{c}\text { Yes } \\
\text { Yes } \\
1488 \\
0.31\end{array}$ & $\begin{array}{c}\text { Yes } \\
\text { Yes } \\
1488 \\
0.19\end{array}$ \\
\hline
\end{tabular}

Notes: This table reports whether there is a differential effects of corruption in municipalities with a private school. Each column presents the results of an OLS regression where the dependent variable is listed at the top of each column. In columns 1 and 2, the dependent variables are dropout and failure rates of children in private schools. In columns 3-6, the dependent variables are the education outcomes for children attending municipal schools (as in the previous tables). Our measure of corruption is an indicator for whether corruption was detected in education. Student characteristics included proportion of male children, proportion of white children, the schooling of the mother, schooling of the father, the proportion of kids with both parents living at home, family size, proportion of households with a computer, proportion of families with running water, proportion of families with electricity, and age dummies. Municipal characteristics included share of population that resides in urban areas, Gini coefficient, GDP per capita in 2004, and expenditure per child in primary school. Robust standard errors clustered at the municipality are displayed in brackets. Significantly different than zero at $99(* * *), 95(* *), 90(*)$ percent confidence. 
TABLE 7: EFFECTS OF CORRUPTION ON SCHOOLING OUTCOMES ACCOUNTING FOR MISMANAGEMENT

\begin{tabular}{lcccc}
\hline \hline \multicolumn{1}{c}{ Dependent variable: } & $\begin{array}{c}\text { Mathematics } \\
(1)\end{array}$ & $\begin{array}{c}\text { Portuguese } \\
(2)\end{array}$ & $\begin{array}{c}\text { Dropout rates } \\
(3)\end{array}$ & $\begin{array}{c}\text { Failure rates } \\
(4)\end{array}$ \\
\hline \multirow{4}{*}{ Corruption in education } & -0.265 & -0.251 & 0.024 & 0.02 \\
& {$[0.081]^{* * *}$} & {$[0.077]^{* * *}$} & {$[0.005]^{* * *}$} & {$[0.009]^{* *}$} \\
Mismanagement & -0.041 & -0.046 & 0.001 & -0.004 \\
& {$[0.018]^{* *}$} & {$[0.017]^{* * *}$} & {$[0.001]$} & {$[0.004]$} \\
& & & & \\
\hline Student characteristics & Yes & Yes & Yes & Yes \\
Municipal characteristics & Yes & Yes & Yes & Yes \\
Number of schools & 1486 & 1486 & 1486 & 1486 \\
R-squared & 0.53 & 0.59 & 0.31 & 0.17 \\
\hline \hline
\end{tabular}

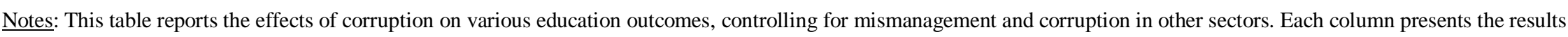
of an OLS regression where the dependent variable is listed at the top of each column. Our measure of corruption is an indicator for whether corruption was detected in education. Our measure of mismanagement is the share of audited service items that found to be associated with poor management practices. Student characteristics included proportion of male children, proportion of white children, the schooling of the mother, schooling of the father, the proportion of kids with both parents living at home, family size, proportion of households with a computer, proportion of families with running water, proportion of families with electricity, and age dummies. Municipal characteristics included share of population that resides in urban areas, Gini coefficient, GDP per capita in 2004, and expenditure per child in primary school. Robust standard errors clustered at the municipality are displayed in brackets. Significantly different than zero at $99(* * *), 95(* *), 90(*)$ percent confidence. 
TABLE 8: THE EFFECTS OF CORRUPTION ON SCHOOLING INPUTS

\begin{tabular}{|c|c|c|c|c|c|c|c|}
\hline \multirow[t]{2}{*}{ Dependent variable: } & \multicolumn{2}{|c|}{$\begin{array}{l}\text { Percentage of teachers with } \\
\text { a higher education degree }\end{array}$} & \multicolumn{2}{|c|}{$\begin{array}{l}\text { Proportion of schools } \\
\text { with a computer lab }\end{array}$} & \multicolumn{2}{|c|}{$\begin{array}{l}\text { Proportion of schools } \\
\text { with a science lab }\end{array}$} & \multirow{2}{*}{$\begin{array}{c}\text { Proportion of } \\
\text { schools with } \\
\text { sanitation } \\
(7)\end{array}$} \\
\hline & $(1)$ & $(2)$ & (3) & $(4)$ & $(5)$ & $(6)$ & \\
\hline Corruption in education & $\begin{array}{c}-0.113 \\
{[0.053]^{* *}}\end{array}$ & $\begin{array}{c}-0.114 \\
{[0.053]^{* *}}\end{array}$ & $\begin{array}{c}-0.06 \\
{[0.026]^{* *}}\end{array}$ & $\begin{array}{c}-0.059 \\
{[0.029]^{* *}}\end{array}$ & $\begin{array}{l}-0.008 \\
{[0.013]}\end{array}$ & $\begin{array}{l}-0.005 \\
{[0.014]}\end{array}$ & $\begin{array}{l}-0.008 \\
{[0.016]}\end{array}$ \\
\hline Initial input in 2001 & $\mathrm{~N}$ & $\mathrm{Y}$ & $\mathrm{N}$ & $\mathrm{Y}$ & $\mathrm{N}$ & $\mathrm{Y}$ & $\mathrm{N}$ \\
\hline Student characteristics & Yes & Yes & Yes & Yes & Yes & Yes & Yes \\
\hline Municipal characteristics & Yes & Yes & Yes & Yes & Yes & Yes & Yes \\
\hline Number of schools & 1488 & 1488 & 1488 & 1150 & 1488 & 1150 & 1488 \\
\hline R-squared & 0.26 & 0.26 & 0.13 & 0.13 & 0.08 & 0.08 & 0.02 \\
\hline
\end{tabular}

$\underline{\text { Notes: }}$ This table reports the effects of corruption on various schooling inputs. Each column presents the results of an OLS regression where the dependent variable is listed at the top of each column. Our measure of corruption is an indicator for whether corruption was detected in education. Student characteristics included proportion of male children, proportion of white children, the schooling of the mother, schooling of the father, the proportion of kids with both parents living at home, family size, proportion of households with a computer, proportion of families with running water, proportion of families with electricity, and age dummies. Municipal characteristics included share of population that resides in urban areas, Gini coefficient, GDP per capita in 2004, and expenditure per child in primary school. Robust standard errors clustered at the municipality are displayed in brackets. Significantly different than zero at $99(* *), 95(* *), 90(*)$ percent confidence. 
TABLE 9: PROBLEMS THAT SCHOOLS FACE BASED ON TEACHER AND PRINCIPAL SURVEYS

\begin{tabular}{|c|c|c|c|c|c|c|c|c|c|}
\hline \multirow{2}{*}{$\begin{array}{c}\text { Survey repondent: } \\
\text { Dependent variable: }\end{array}$} & \multicolumn{4}{|c|}{ Teacher } & \multicolumn{5}{|c|}{ Principal } \\
\hline & $\begin{array}{l}\text { Insufficient } \\
\text { resources } \\
(1) \\
\end{array}$ & $\begin{array}{c}\text { Insufficient } \\
\text { teaching supplies } \\
(2)\end{array}$ & $\begin{array}{l}\text { Lack of } \\
\text { teachers } \\
\text { (3) }\end{array}$ & $\begin{array}{c}\text { Disciplinary } \\
\text { problems among } \\
\text { students } \\
(4)\end{array}$ & $\begin{array}{l}\text { Insufficient } \\
\text { resources } \\
(5) \\
\end{array}$ & $\begin{array}{c}\text { Insufficient } \\
\text { teaching supplies } \\
(6)\end{array}$ & $\begin{array}{c}\text { Lack of } \\
\text { teachers } \\
(7)\end{array}$ & $\begin{array}{c}\text { Disciplinary } \\
\text { problems among } \\
\text { students } \\
\text { (8) }\end{array}$ & $\begin{array}{l}\text { Provided } \\
\text { teacher training } \\
\text { (9) }\end{array}$ \\
\hline Corruption in education & $\begin{array}{c}0.072 \\
{[0.034]^{* *}}\end{array}$ & $\begin{array}{c}0.066 \\
{[0.032]^{* *}}\end{array}$ & $\begin{array}{c}-0.004 \\
{[0.031]}\end{array}$ & $\begin{array}{c}0.007 \\
{[0.029]}\end{array}$ & $\begin{array}{c}0.045 \\
{[0.034]}\end{array}$ & $\begin{array}{c}0.106 \\
{[0.035]^{* * *}}\end{array}$ & $\begin{array}{c}-0.014 \\
{[0.030]}\end{array}$ & $\begin{array}{l}-0.032 \\
{[0.031]}\end{array}$ & $\begin{array}{c}-0.106 \\
{[0.047]^{* *}}\end{array}$ \\
\hline Student characteristics & Yes & Yes & Yes & Yes & Yes & Yes & Yes & Yes & Yes \\
\hline Municipal characteristics & Yes & Yes & Yes & Yes & Yes & Yes & Yes & Yes & Yes \\
\hline Number of schools & 1488 & 1488 & 1488 & 1488 & 1488 & 1488 & 1488 & 1488 & 1488 \\
\hline R-squared & 0.02 & 0.05 & 0.04 & 0.01 & 0.05 & 0.08 & 0.02 & 0.02 & 0.04 \\
\hline
\end{tabular}

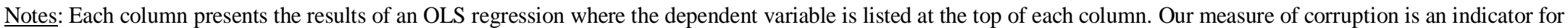
whether corruption was detected in education. In columns 1-4, the data come from a survey conducted with a teacher. In columns 5-9, the data come from a survey conducted with the principal. Student characteristics included proportion of male children, proportion of white children, the schooling of the mother, schooling of the father, the proportion of kids with both parents living at home, family size, proportion of households with a computer, proportion of families with running water, proportion of families with electricity, and age dummies. Municipal characteristics included share of population that resides in urban areas, Gini coefficient, GDP per capita in 2004, and expenditure per child in primary school. Robust standard errors clustered at the municipality are displayed in brackets. Significantly different than zero at $99(* * *), 95(* *), 90(*)$ percent confidence. 